Turupçu-Doğan, A. \& Ömeroğlu, E. (2019). Early Childhood Teachers' Views About the Use of Questions in Early Childhood Education Program Assessment. Bartın University Journal of Faculty of Education, 8(2), 524-548.

Bartın University Journal of Faculty of Education, 8(2), 524-548

Bartın Üniversitesi Eğitim Fakültesi Dergisi, 8(2), 524-548

buefad.bartin.edu.tr

\title{
Early Childhood Teachers' Views About the Use of Questions in Early Childhood Education Program Assessment
}

Aysun Turupcu Doğan*a, Esra Ömeroğlu ${ }^{\mathrm{b}}$

\begin{tabular}{l} 
Article Info \\
\hline DOI: $10.14686 /$ buefad.481827 \\
\hline Article History: \\
Received $\quad 12.11 .2018$ \\
Accepted 12.03 .2019 \\
Published $\quad 30.06 .2019$ \\
\hline Keywords: \\
Early childhood education, \\
Program assessment, \\
Evaluation questions. \\
\hline Article Type: \\
Research article \\
\end{tabular}

\begin{abstract}
The aim of this study is to determine the opinions of preschool teachers about the types of evaluation questions (descriptive questions, affective questions, questions on objectives, and questions associated with daily life) preferred by teachers during the preparation and application phases of teaching activities. Also, to determine whether or not there is any relation between the frequency of use of evaluation questions within education programs and training about the evaluation of young children. The sample of the study consisted of 323 preschool teachers. Data was gathered through the screening model. A questionnaire was used as the data collection tool and Chi-Square Test $\chi 2$ was employed in the data analysis. It was determined that preschool teachers prefer "descriptive questions" and "questions on objectives" more than "affective questions" and "questions associated with daily life." Teachers declared that they mostly preferred "questions on objectives" to enhance children's skills and to perform end-of-day assessments as well. Additionally, there was no significant difference found between the frequency of teachers' use of "questions associated with daily life" and having training/seminars on the evaluation of young children.
\end{abstract}

\section{Okul Öncesi Eğitim Programının Değerlendirme Sorularının Kullanımına Yönelik Öğretmen Görüssleri}

\begin{tabular}{|c|c|}
\hline \multicolumn{2}{|c|}{ Makale Bilgisi } \\
\hline \multicolumn{2}{|c|}{ DOI: $10.14686 /$ buefad.481827 } \\
\hline \multicolumn{2}{|c|}{ Makale Geçmişi: } \\
\hline Geliş & 12.11 .2018 \\
\hline Kabul & 12.03 .2019 \\
\hline Yayın & 30.06 .2019 \\
\hline \multicolumn{2}{|c|}{$\begin{array}{l}\text { Anahtar Kelimeler: } \\
\text { Okul öncesi eğitimi, } \\
\text { Program değerlendirmesi, } \\
\text { Değerlendirme soruları. }\end{array}$} \\
\hline \multicolumn{2}{|c|}{$\begin{array}{l}\text { Makale Türü: } \\
\text { Araştırma makalesi }\end{array}$} \\
\hline
\end{tabular}

Öz

$\mathrm{Bu}$ araştırmanın amacı okul öncesi öğretmenlerinin etkinliklerin hazırlanma ve uygulanma aşamasında, eğitim programlarında yer alan değerlendirme sorularının (betimleyici sorular, duyuşsal sorular, kazanım ve göstergelere yönelik sorular ve yaşamla ilişkilendirme soruları) hangilerini tercih ettiklerini belirlemektir. Ayrıca okul öncesi öğretmenlerinin çocukların değerlendirilmesi konusu üzerine aldıkları eğitimin bu soruları kullanım sıklıklarına etkisi olup olmadığına yönelik görüşlerini belirlenmesi amaçlanmıştır. Bu çalışmada tarama modeli kullanılmıştır. Çalışma grubunu 323 okul öncesi öğretmeni oluşturmuştur. Öğretmenlerin görüşleri oluşturulan anket yoluyla elde edilmiştir ve veriler iki değişken için kay-kare Testi kullanılarak analiz edilmiştir. Okul öncesi öğretmenlerin "betimleyici soruları" ve "kazanım ve göstergelere yönelik soruları", "duyuşsal sorular" ve "yaşamla ilişkilendirme sorularına" göre daha çok tercih ettikleri sonucuna ulaşılmıştır. Öğretmenler, çocukların becerilerini üst düzeye çıkarmak ayrıca gün sonu değerlendirmesi yapmak için öncelikli olarak "kazanım ve göstergelere yönelik soruları" hazırlayıp sorduklarını ifade etmiştir. Ayrıca öğretmenlerin değerlendirme konusu ile ilgili eğitim almış olmalarının özellikle "yaşamla ilişkilendirme sorularını" kullanım sıklıkları arasında anlamlı bir fark olmadığ 1 belirlenmiștir 


\section{Introduction}

Children's healthy growth, development and learning can be realized through education that supports "whole child" initiatives that ensure students are healthy, safe, engaged, supported and challenged, and provides for their long-term success. When such training is prepared within a developmentally appropriate program, a longitudinal follow-up opportunity can be obtained in all areas of development based on learners' individual differences. Evaluation of the program is considered an indispensable part of a developmentally appropriate program. The assessment part of a program may provide the child, their family, teacher, and the school with the necessary information to produce ideas, and to thereby decide on the child's education and development. In addition to standard testing, alternative assessment methods are preferred for the preschool period in the evaluation of programs and learning. Researchers and educators define informal assessment as a promising alternative to standardized testing (Bricker, Pretti-Frontczak, Johnson, \& Straka, 2002; Downs \& Strand, 2006). With this informal assessment, teachers can evaluate and support the children individually in the process through one-toone participation. The teacher can also provide efficient feedback by choosing the most appropriate alternative assessment techniques such as observation, questioning, and interviewing based on the needs of the children and the classroom atmosphere.

With questioning preferred as an important method used in education for many years, it has constituted an important and most effective part of learning activities (Muijs \& Reynolds, 2005; Tan, 2007). While good questions are the most effective tools of education, a good teacher is considered to be the person who knows how to use questions to the greatest effect (MyHill \& Dunkin, 2002). As a term, a question is defined as a sentence intended for the purpose of prompting thinking or as a form of providing information (MacNaughton \& Williams, 2004), while teachers can prefer questioning for many purposes in the educational process. These objectives could be listed as; to draw attention, to support high-level thinking skills, to express and to reorient emotions (Borich, 2013), to determine the prejudices and misconceptions of children, to analyze discussions, to create bridges between old and new concepts, to support the use of new information in different content (Yip, 2004), to initiate class discussions/debates (Nassaji \& Wells, 2000), to assess what children learn (Petty, 1993), and to help children complete their activities (Erdoğan \& Campbell, 2008).

The use of questions included in training has been defined differently by various researchers as "correct," "necessary," "producer," "guide" and "efficient" (Kohn, 2015). Questions that may be defined as a "guide" are listed in the six steps according to Bloom's taxonomy in 1956, and these are stated as knowledge, comprehension, application, analysis, synthesis, and evaluation (Cecil \& Preifer, 2011). This taxonomy was updated by Lorin Anderson and his colleagues in 1999 with the idea that there were more effective factors on learning and teaching (Yurdakan, 2012). The updated taxonomy is categorized under two dimensions as "knowledge" and "cognitive processes". The "knowledge" dimension classified as "factual, conceptual, procedural and metacognitive" while the "cognitive processes" dimension consisted of six steps as "remember, understand, apply, analyze, evaluate and create" (Krathwohl, 2002). Recalling the information from the mind is the matter of the first step of the knowledge dimension. In this step, information and memorization- oriented questions are produced rather than thinking and interpreting. For the understand step in which the basis is to create meaning from educational materials and experiences, the verbs 'find', 'compare', 'explain' and 'summarize' are used in the questions. In the third step, application, there is the use or application of the appropriate process in a given case. While separating a concept and discovering how these parts are related to the whole is carried out in the analysis step, standards based judgments are created by controlling and criticizing in the evaluation stage. In the last step of Bloom's updated taxonomy, 'create' focuses on the ability of the child to assemble pieces to create something new. The steps of 'analyze', 'evaluate' and especially the 'create' constitute the steps in which high-level questions are addressed. At these levels, individuals are encouraged to create their own judgments by supporting creative and critical thinking skills. Questions planned for the training period should be prepared in accordance with the levels of cognition in children, and for their level of development (Storey, 2004). In addition, the most frequently used questions in the literature are examined as closed questions and open-ended questions based on the structure of the questions. While closed questions require short answers at the level of knowledge, open-ended questions require longer and more descriptive answers that will lead the child to think and convey their ideas (Bay, 2016; MacNaughton \& Williams, 2004).

Researches have shown that the types of questions used by teachers are very limited and that teachers mostly prefer closed questions and direct knowledge questions (Bay \& Hartman, 2015; Meacman, Vukelich, Han, \& 
Buell, 2014; Storey, 2004). Teachers' questions in the process of education provide an opportunity to connect with what children know and what they need to query and reflect with their thoughts (Fisher, 1995). Therefore, creative and open-ended questions can be considered the most important tools for teachers during training. However, asking creative questions requires critical-thinking skills and significant resources (McComas \& Abraham Rossier, 2005), and therefore these questions can be seen as time-wasters. For this reason, teachers should formulate questions carefully prior to preparing a training program in line with the needs of the children and the targeted objectives. Asking effective questions supports learning rather than controlling children's knowledge (MacNaughton \& Williams, 2004; Vogler, 2005), allowing them to develop critical-thinking, decision-making and problem-solving skills (Sellappah, Hussey, Blackmore, \& McMurray, 1998). In addition, questioning using "why," and "how" (How do you...?, Why do you think...?) offers children the opportunity to understand, to dream, to feel, and to rethink their own experiences (MacNaughton \& Williams, 2004). Diversity in the preferred questions can increase the difficulty and complexity of the children's responses (Massey, Pence, Justice, \& Bowles, 2008). In addition, the questions that force children to cognitively support their self-awareness within the classroom, increase their participation in activities and lead to deep learning (Zeegers \&Elliott,2018). However, whether closed or openended questions are employed in the process of education and evaluation, children react less to comments and statements without questioning than dialogue that includes different questions (Meacman et al., 2014). For this reason, teachers should always include questions through each of the steps of teaching and learning, including evaluation. In addition, teachers should be able to determine the objectives, the types of questions, and when questions should be asked. Teachers are expected to know that they should prepare high-level questions to support critical-thinking and problem-solving skills, while asking low-level questions to determine children's strengthens and weaknesses (Bay, 2016; Storey, 2004).

Questioning in education and especially within the evaluation process is also included in preschool education programs. Turkey's Ministry of National Education (MoNE) Preschool Program defines that there should be multidimensional evaluation, and its basic principle states that "results of evaluation should be used effectively to enhance the development of children, teachers and the program as well” (Milli Eğitim Bakanlığ [Ministry of National Education], 2013, p. 13). Evaluation, which is considered an important part of the education process, is discussed in detail within a separate section of the Turkish preschool education program. Besides the evaluation of children's and teachers' development, guiding questions have been identified in order for teachers to guide the evaluation of the program. These questions are categorized as "Descriptive Questions," "Affective Questions," "Questions based on Objectives" and "Questions Associated with Daily Life" (Milli Eğitim Bakanlığ1 [Ministry of National Education], 2013). Descriptive questions are seen as the first stage of evaluation, with answers consisting of what is done within an activity. Questions based on objectives are included in order to determine how much of the objectives in the activity plan have been achieved. While affective questions give the opportunity for children to share their opinions and feelings about the activity process, an environment is provided for children to establish a relationship between their experiences and life using questions associated with daily life. Example questions are provided within the program in order to guide teachers. Descriptive questions are questions of what, where, and who, whilst questions on objectives focus on whether or not the children have achieved the intended learning outcomes. In affective questions, children are given the opportunity to understand and to analyze their own emotions, as well as those of others. Finally, in questions associated with daily life, the aim is to assure permanence of what the children have learned. These questions are directed to the children at the end of the program activities so as to help them analyze, evaluate their learning and create new things through linking back to their own life in evaluating the activity process.

Although these questions are intended to guide teachers in preparing and implementing activities, the assessment process within preschooling does not attract adequate attention. Most of the studies were conducted to determine the teachers' assessment methods preference and their opinions on these methods rather than the questions that used in the preschool classrooms (Buldu, 2010; Dennis, Rueter \& Simpson, 2014; Can Gül, 2009; Hanes, 2009; Kaya, 2018; Turupcu, 2014). However, the aim of this study is specifically to pay attention to teachers' preference of questions and the frequency of use of these questions for evaluation process of preschoolers, therefore this study is thought as important for preschool education literacy. Based on the published research, during the evaluation process, teachers mostly prefer lower-level questions and closed questions (Bay, 2016; Baysen, 2006; Lee, 2010; Storey, 2004). For the current study, four aims are determined for the preschool 
evaluation process; "preparing questions in a way that can be answered in different learning centers," "preparing questions that can raise children's skills to the highest level," "asking questions by considering developmental characteristics for development follow-up" and "performing end-of-day evaluation with questions." This study is considered important in terms of defining which questions are preferred the most from "descriptive questions," "affective questions," "questions based on objectives," and "questions associated with daily life," and also to provide a different perspective by examining the frequency of occurrence of such question types. Because when teachers gain an awareness of how often they choose which questions for evaluation process of pre-schoolers, they will be able to direct more appropriate questions to children and encourage them to ask questions. As a result, children's understanding skills can be supported (Nystrand, Wu, Gamoran, Zeiser \& Long, 2003), and children will feel more valued and motivated with conversations and questions that continue during the activities (Mercer \& Howe, 2012). This study is significant in terms of teachers can see the overall picture over the availability of the proposed evaluation questions in the pre-school education programs in Turkey. So, the questions facilitate the negotiation environment to evaluate and assess the ideas of children. Thus, there will be further progress in critical thinking and problem solving skills of children (Günel, Kıngır \& Geban, 2012; Mercer \& Howe, 2012; Scott, Mortimer \& Aguiar, 2006)

The aim of this study is to answer the following research questions based on the feedback of preschool teachers about the question types they prefer in order to reach the goals determined during the evaluation of their education;

1- Which evaluation questions are preferred by preschool teachers in early childhood education programs; descriptive questions, affective questions, questions on objectives, or questions associated with daily life?

2- Is there any significant difference between the frequency of question type usage by preschool teachers and their having received training about the evaluation of preschool children?

\section{Method}

This section details the research design, research sample, data collection tool, data collection, and data analysis of the study.

\section{Research Design}

In this study, the qualitative research methods screening model was preferred because the aim is to understand the views of teachers in preschool education institutions, therefore necessitating reaching teachers within the wider audience. In screening research, the views of a wider community should be taken into account, while the data should include answers to questions directed at the participants (Fraenkel \& Wallen, 2006). In addition, such studies should focus on how the participants express their views, rather than the reasons of the participants. In the current study, it is aimed to determine which question types offered in preschool education programs are asked by teachers in the process of preparation and follow-up of their activities.

\section{Research Sample}

The sample of the study was defined by maximum diversity sampling, which is a type of objective sampling. The reason for this is in order to obtain specific clues about the universe without being concerned with generalization by considering different samples in line with the determined problem (Büyüköztürk, Kılıç Çakmak, Akgün, Karadeniz, \& Demirel, 2014). In addition, by presenting similarities and differences in various situations, evaluation of the problem from different perspectives may be possible. The sample of the current study is formed of a total of 323 preschool teachers working in different provinces of Turkey. Table 1 shows the demographics of the sample.

Table 1 shows the distribution of preschool teachers according to age, gender, education, graduating department, seniority, the age group and class size they work with, and having received training/ seminar (on evaluation within preschool education). In general, it was determined that half of the teachers were in the 21-30year age group and $92 \%$ are female. Additionally, $81 \%$ of the teachers held a Bachelor's Degree and $71.8 \%$ graduated from the Department of Preschool Education. While $41.5 \%$ of the teachers were in the first five years of their professional life, about half worked with 5-year-old children, and 25\% stated that they had more than 21 children in their class. Finally, $90.7 \%$ of the teachers in the sample had not attended training or a seminar on evaluation within preschool education. 
Table 1. Demographic Information of Preschool Teachers

\begin{tabular}{|c|c|c|c|}
\hline & & $\mathrm{F}$ & $\%$ \\
\hline \multirow{3}{*}{ Age } & $21-30$ & 165 & 51.1 \\
\hline & $31-40$ & 114 & 35.3 \\
\hline & $41+$ & 44 & 13.6 \\
\hline \multirow{2}{*}{ Gender } & Female & 299 & 92.6 \\
\hline & Male & 24 & 7.4 \\
\hline \multirow[b]{2}{*}{ Education } & Bachelor's Degree & 262 & 81.1 \\
\hline & $\begin{array}{l}\text { Other } \\
\text { (Vocational High School, Associate Degree) }\end{array}$ & 61 & 18.9 \\
\hline \multirow{2}{*}{ Department (graduation) } & Preschool Education & 232 & 71.8 \\
\hline & Other (Child Development/and Education) & 91 & 28.2 \\
\hline \multirow{4}{*}{ Seniority } & $0-5$ yrs & 134 & 41.5 \\
\hline & $6-10 \mathrm{yrs}$ & 102 & 31.6 \\
\hline & $11-15 \mathrm{yrs}$ & 47 & 14.6 \\
\hline & $16 \mathrm{yrs}+$ & 40 & 12.4 \\
\hline \multirow{3}{*}{ Age Group } & $3-4$ yrs & 87 & 26.9 \\
\hline & 5 yrs & 161 & 49.8 \\
\hline & $6 \mathrm{yrs}$ & 75 & 23.2 \\
\hline \multirow{3}{*}{ Class size } & $10-15$ children & 119 & 36.8 \\
\hline & $16-20$ children & 125 & 38.7 \\
\hline & 21 children + & 79 & 24.5 \\
\hline \multirow{2}{*}{ Having training/seminar } & Yes & 30 & 9.3 \\
\hline & No & 293 & 90.7 \\
\hline
\end{tabular}

\section{Data Collection Tool}

In this study, the aim was to describe the views of teachers about the use of evaluation questions. A questionnaire was preferred as the data collection tool. With surveys, which are advantageous in terms of reaching larger groups within a shorter timeframe and with lower costs, results are expressed as the basic number of participants responding to questionnaire items (Büyüköztürk et al., 2014).

The questionnaire consists of two parts. In the first part, questions are used to obtain the demographic characteristics of the participants, whilst the second part consists of questions regarding the participants views. After performing a review of the literature, a draft questionnaire form was prepared under two main headings, as preparation and application of evaluation questions. The draft form was sent to two pre-school education and a measurement and evaluation expert to get the feedback based on the criteria; consistency with the purpose, scope, content of study and coherence of language. Based on the feedback of experts, the incoherency of the questions was checked. After that, it is considered sufficient to apply pretest to participants of up to $20 \%$ of the sample size (Büyüköztürk et al., 2014); and therefore, a total of 67 preschool teachers participated in a pilot test of the questionnaire. After these preparations to support the instrument's validity and reliability, three questionnaire items which were not sufficiently understood by the pilot participants were removed.

The final form of the questionnaire consisted of 13 items. Participants were expected to respond to each questions by taking into account the four types of assessment questions; "Descriptive Questions," "Affective Questions," "Questions based on Objectives," and "Questions Associated with Daily Life" in Turkey's Ministry of National Education (MoNE) Preschool Education Program (Milli Eğitim Bakanlı̆̆ [Ministry of National Education], 2013). The prepared questions were formed as five-point, Likert-type items examining teachers' frequency of usage of each evaluation question type.

\section{Data Collection}


During the data collection process, online questionnaires were completed as a means to reaching a larger number of participants. Additionally, questionnaires were conducted with teachers in Ankara on a face-to-face basis. In terms of the quality of the data, some of the questionnaires were excluded from the analysis, and as a result, a total of 323 questionnaires were included.

\section{Data Analysis}

The quantitative research method was preferred for this study, with data collected by means of a survey. For this reason, data analysis was performed using Chi-Square Test 2 for two variables from nonparametric statistics. This test, which is frequently used in screening studies, aimed to determine whether or not there is a relationship between two categorical variables. Three different solutions are presented if the number of cell less than 5 is more than $20 \%$ of whole. One of these is to merge into the relevant line or column. The aim is to increase the observed frequencies and increase the expected values (Büyüköztürk, 2014). In this study, due to the more in the number of cell exceeding specified value, the likert items were merged. The three categories; "never," "rarely," and "sometimes" were combined under the title "occasionally." The other categories were named as "mostly" and "always."

\section{Findings}

Table 2 shows which assessment questions were preferred by teachers in the preparation and implementation of their activity plans in order to reach the determined goals. In addition, Table 3 shows the Chi-Square Test results on whether or not the usage frequency of teachers' preference of evaluation questions differs according to the teachers' having taken training or attended a seminar on evaluation within preschool education. Furthermore, Table 3 shows four different Chi-Square Test results, one for each type of evaluation question (descriptive, affective, questions on objectives, and questions associated with daily life).

Table 2 shows that the teachers prefer "descriptive questions" with a rate of $49.5 \%$ for questions that can be answered in different learning centers while preparing activity plans. While the children maintained their activities in different learning centers, only $4.6 \%$ of the teachers stated that they were preparing "questions associated with daily life" in order to evaluate the children. Another aim of teachers in the evaluation process of education is to increase the skills of the children to the highest level. For this purpose, it was concluded that $48.9 \%$ of the teachers prepared "questions on objectives" and $35.9 \%$ of them prepared "descriptive questions"; however, "affective questions" were preferred by only $5.3 \%$ of teachers for this goal.

The most equal distribution among the teachers' choice of questions was for questions asked as follow-up to the children's development. Firstly, teachers preferred "descriptive questions" (28.9\%), then "affective questions" $(26.0 \%)$, "questions on objectives" $(23.5 \%)$ and, finally, "questions associated with daily life" $(21.4 \%)$ in order to be able to evaluate children's development.

Table 2. Evaluation Questions Preference of Preschool Teachers

\begin{tabular}{|c|c|c|c|c|}
\hline $\begin{array}{r}\text { Evaluation Question } \\
\text { Preference }\end{array}$ & $\begin{array}{l}\text { Descriptive } \\
\text { questions }\end{array}$ & $\begin{array}{l}\text { Questions on } \\
\text { objectives }\end{array}$ & $\begin{array}{l}\text { Affective } \\
\text { questions }\end{array}$ & $\begin{array}{c}\text { Questions } \\
\text { Associated } \\
\text { w/ daily life }\end{array}$ \\
\hline Aims & $f / \%$ & $f / \%$ & $f / \%$ & $f / \%$ \\
\hline $\begin{array}{l}\text { Preparing questions in the way that can be } \\
\text { answered in different learning centers }\end{array}$ & $\begin{array}{c}160 \\
(49.5 \%)\end{array}$ & $\begin{array}{c}126 \\
(39.0 \%)\end{array}$ & $\begin{array}{c}22 \\
(6.8 \%)\end{array}$ & $\begin{array}{c}15 \\
(4.6 \%)\end{array}$ \\
\hline $\begin{array}{l}\text { Preparing questions that can raise } \\
\text { children's skills to the highest level }\end{array}$ & $\begin{array}{c}116 \\
(35.9 \%)\end{array}$ & $\begin{array}{c}158 \\
(48.9 \%)\end{array}$ & $\begin{array}{c}17 \\
(5.3 \%)\end{array}$ & $\begin{array}{c}32 \\
(9.9 \%)\end{array}$ \\
\hline $\begin{array}{l}\text { Asking questions by considering } \\
\text { developmental characteristics for } \\
\text { development follow-up }\end{array}$ & $\begin{array}{c}93 \\
(28.8 \%)\end{array}$ & $\begin{array}{c}76 \\
(23.5 \%)\end{array}$ & $\begin{array}{c}84 \\
(26.0 \%)\end{array}$ & $\begin{array}{c}70 \\
(21.7 \%)\end{array}$ \\
\hline Doing end-of-day evaluation with questions & 102 & 128 & 66 & 27 \\
\hline
\end{tabular}




$\begin{array}{llll}(31.6 \%) & (39.6 \%) & (20.4 \%) & (8.4 \%)\end{array}$

As seen in Table 2, only $8.4 \%$ of teachers ask "questions associated with daily life" in order to perform an endof-day assessment, and also that they mostly preferred "questions on objectives" with a ratio of $39.6 \%$ for this purpose. It is also seen that teachers have a tendency to prefer "descriptive questions" and "questions on objectives" to reach their goals, and that "questions associated with daily life" are the evaluation question types least preferred by early childhood teachers.

Table 3 provides the results of the Chi-Square Tests used to determine whether or not the usage frequency of the evaluation questions used by the teachers in preparing and implementing the activity plan varied according to them having attended a seminar or training on the evaluation of young children.

For the purpose of preparing questions that can be answered in different learning centers, $36.7 \%$ of the teachers who had received training or attended a seminar on evaluation in preschool education always used "descriptive questions," while 48.8\% who had not attend any training/seminar stated that they occasionally preferred "descriptive questions." In another result of the study, "affective questions" were found to be mostly preferred by $50 \%$ of teachers having received training, and $46.4 \%$ of teachers who had not. While $20 \%$ of the teachers who had been trained preferred "questions on objectives" occasionally, the teachers who had not been trained always used this type of question at a rate of $23.2 \%$. Finally, the "questions associated with daily life" were found to be mostly preferred by teachers who had been trained at a rate of $40 \%$, while $42 \%$ of the non-trained teachers only asked these questions occasionally. The results of the Chi-Square Test showed no significant differences between the usage frequency "descriptive questions" and "questions on objectives" and having received training on evaluation: $\chi^{2}(\mathrm{SD}=2, \mathrm{n}=323)=5.04, \chi^{2}(\mathrm{SD}=2, \mathrm{n}=323)=3.98, \mathrm{p}>.05$. On the other hand, significant differences were seen between the usage frequency of "affective questions" and "questions associated with daily life," and having attending training or seminars on the evaluation of young children: $\chi 2(\mathrm{SD}=2, \mathrm{n}=323)=9.11$ and $\chi^{2}(\mathrm{SD}=2, \mathrm{n}$ $=323)=7.54, \mathrm{p}<.05$. 
Turupcu Doğan \& Ömeroğlu

Table 3. Chi-Square Test Result on Teachers' Frequency of Use of Evaluation Questions According with the Having Training/Seminars on Assessment*

\begin{tabular}{|c|c|c|c|c|c|c|c|c|c|c|c|c|c|c|c|c|c|c|c|c|c|c|}
\hline \multirow[b]{2}{*}{ 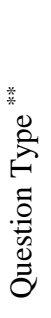 } & \multirow{2}{*}{\multicolumn{2}{|c|}{$\begin{array}{l}\text { Having } \\
\text { received } \\
\text { training on } \\
\text { evaluation }\end{array}$}} & \multicolumn{5}{|c|}{$\begin{array}{l}\text { Preparing questions in the way that be } \\
\text { answered in different learning centers }\end{array}$} & \multicolumn{5}{|c|}{$\begin{array}{l}\text { Preparing questions that can raise } \\
\text { children's skills to the highest level }\end{array}$} & \multicolumn{5}{|c|}{$\begin{array}{l}\text { Asking questions by considering } \\
\text { developmental characteristics for } \\
\text { development follow-up }\end{array}$} & \multicolumn{5}{|c|}{$\begin{array}{l}\text { Doing end-of-day evaluation with } \\
\text { questions }\end{array}$} \\
\hline & & & 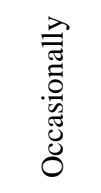 & $\frac{\overrightarrow{w^{2}}}{\sum_{0}^{0}}$ & $\sum_{\substack{\infty \\
\ll}}^{\infty}$ & $\mathrm{p}$ & $\chi^{2}$ & 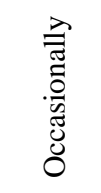 & $\begin{array}{l}\overrightarrow{\vec{w}} \\
\text { 总 }\end{array}$ & 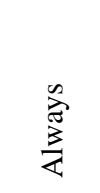 & $\mathrm{p}$ & $\chi^{2}$ & 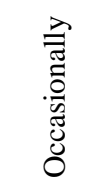 & $\begin{array}{l}\overrightarrow{\tilde{b}^{2}} \\
\sum_{\Sigma}^{0}\end{array}$ & 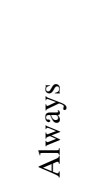 & $\mathrm{p}$ & $\chi^{2}$ & 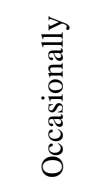 & $\begin{array}{l}\overrightarrow{\vec{n}} \\
\stackrel{0}{\sum^{0}}\end{array}$ & 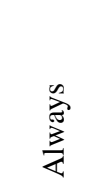 & $\mathrm{p}$ & $\chi^{2}$ \\
\hline \multirow{2}{*}{1} & Yes & $\begin{array}{l}n \\
(\%)\end{array}$ & $\begin{array}{l}9 \\
(30.0)\end{array}$ & $\begin{array}{l}10 \\
(33.3)\end{array}$ & $\begin{array}{l}11 \\
(36.7)\end{array}$ & \multirow{2}{*}{.081} & \multirow{2}{*}{5.038} & $\begin{array}{l}8 \\
(26.7)\end{array}$ & $\begin{array}{l}8 \\
(26.7)\end{array}$ & $\begin{array}{l}14 \\
(46.7)\end{array}$ & \multirow{2}{*}{.102} & \multirow{2}{*}{4.567} & $\begin{array}{l}4 \\
(13.3)\end{array}$ & $\begin{array}{l}9 \\
(30.0)\end{array}$ & $\begin{array}{l}17 \\
(56.7)\end{array}$ & \multirow{2}{*}{.258} & \multirow{2}{*}{2.708} & $\begin{array}{l}11 \\
(36.7)\end{array}$ & $\begin{array}{l}6 \\
(20.0)\end{array}$ & $\begin{array}{l}13 \\
(43.3)\end{array}$ & \multirow{2}{*}{.041} & \multirow{2}{*}{6.412} \\
\hline & No & $\begin{array}{l}n \\
(\%)\end{array}$ & $\begin{array}{l}143 \\
(48.8)\end{array}$ & $\begin{array}{l}88 \\
(30.0)\end{array}$ & $\begin{array}{l}62 \\
(21.2)\end{array}$ & & & $\begin{array}{l}101 \\
(34.5)\end{array}$ & $\begin{array}{l}110 \\
(37.7)\end{array}$ & $\begin{array}{l}82 \\
(28.0)\end{array}$ & & & $\begin{array}{l}79 \\
(27.0)\end{array}$ & $\begin{array}{l}29 \\
(27.0)\end{array}$ & $\begin{array}{l}135 \\
(46.1)\end{array}$ & & & $\begin{array}{l}141 \\
(48.1)\end{array}$ & $\begin{array}{l}86 \\
(29.4)\end{array}$ & $\begin{array}{l}66 \\
(22.5)\end{array}$ & & \\
\hline \multirow[b]{2}{*}{2} & Yes & $\begin{array}{l}n \\
(\%)\end{array}$ & $\begin{array}{l}3 \\
(10.0)\end{array}$ & $\begin{array}{l}15 \\
(50.0)\end{array}$ & $\begin{array}{l}12 \\
(40.0)\end{array}$ & \multirow{2}{*}{.011} & \multirow{2}{*}{9.106} & $\begin{array}{l}2 \\
(6.7)\end{array}$ & $\begin{array}{l}15 \\
(50.0)\end{array}$ & $\begin{array}{l}13 \\
(43.3)\end{array}$ & \multirow{2}{*}{.068} & \multirow{2}{*}{5.370} & $\begin{array}{l}7 \\
(23.3)\end{array}$ & $\begin{array}{l}5 \\
(16.7)\end{array}$ & $\begin{array}{l}18 \\
(60.0)\end{array}$ & & & $\begin{array}{l}9 \\
(30.0)\end{array}$ & $\begin{array}{l}10 \\
(33.3)\end{array}$ & $\begin{array}{l}11 \\
(36.7)\end{array}$ & \multirow{2}{*}{.249} & \multirow{2}{*}{2.779} \\
\hline & No & $\begin{array}{l}n \\
(\%)\end{array}$ & $\begin{array}{l}96 \\
(32.8)\end{array}$ & $\begin{array}{l}136 \\
(46.4)\end{array}$ & $\begin{array}{l}61 \\
(20.8)\end{array}$ & & & $\begin{array}{l}64 \\
(21.8)\end{array}$ & $\begin{array}{l}148 \\
(50.5)\end{array}$ & $\begin{array}{l}81 \\
(27.6)\end{array}$ & & & $\begin{array}{l}106 \\
(36.2)\end{array}$ & $\begin{array}{l}48 \\
(16.4)\end{array}$ & $\begin{array}{l}139 \\
(47.4)\end{array}$ & .338 & 2.168 & $\begin{array}{l}121 \\
(41.3)\end{array}$ & $\begin{array}{l}103 \\
(35.2)\end{array}$ & $\begin{array}{l}69 \\
(23.5)\end{array}$ & & \\
\hline \multirow{2}{*}{3} & Yes & $\begin{array}{l}n \\
(\%)\end{array}$ & $\begin{array}{l}6 \\
(20.0)\end{array}$ & $\begin{array}{l}12 \\
(40.0)\end{array}$ & $\begin{array}{l}12 \\
(40.0)\end{array}$ & \multirow{2}{*}{.023} & \multirow{2}{*}{7.536} & $\begin{array}{l}1 \\
(3.3)\end{array}$ & $\begin{array}{l}12 \\
(40.0)\end{array}$ & $\begin{array}{l}17 \\
(56.7)\end{array}$ & \multirow{2}{*}{.033} & \multirow{2}{*}{6.806} & $\begin{array}{l}5 \\
(16.7)\end{array}$ & $\begin{array}{l}9 \\
(30.0)\end{array}$ & $\begin{array}{l}16 \\
(53.3)\end{array}$ & & & $\begin{array}{l}9 \\
(30.0)\end{array}$ & $\begin{array}{l}8 \\
(26.7)\end{array}$ & $\begin{array}{l}13 \\
(43.3)\end{array}$ & \multirow{2}{*}{.029} & \multirow{2}{*}{7.112} \\
\hline & No & $\begin{array}{l}n \\
(\%)\end{array}$ & $\begin{array}{l}131 \\
(44.7)\end{array}$ & $\begin{array}{l}94 \\
(32.1)\end{array}$ & $\begin{array}{l}68 \\
(23.2)\end{array}$ & & & $\begin{array}{l}68 \\
(23.2)\end{array}$ & $\begin{array}{l}106 \\
(36.2)\end{array}$ & $\begin{array}{l}119 \\
(40.6)\end{array}$ & & & $\begin{array}{l}44 \\
(15.0)\end{array}$ & $\begin{array}{l}107 \\
(36.5)\end{array}$ & $\begin{array}{l}142 \\
(48.5)\end{array}$ & .878 & . & $\begin{array}{l}160 \\
(54.6)\end{array}$ & $\begin{array}{l}60 \\
(20.5)\end{array}$ & $\begin{array}{l}73 \\
(24.9)\end{array}$ & & \\
\hline \multirow[b]{2}{*}{4} & Yes & $\begin{array}{l}n \\
(\%)\end{array}$ & $\begin{array}{l}7 \\
(23.3)\end{array}$ & $\begin{array}{l}12 \\
(40.0)\end{array}$ & $\begin{array}{l}11 \\
(36.7)\end{array}$ & \multirow{2}{*}{.137} & \multirow{2}{*}{3.982} & $\begin{array}{l}2 \\
(6.7)\end{array}$ & $\begin{array}{l}9 \\
(30.0)\end{array}$ & $\begin{array}{l}19 \\
(63.3)\end{array}$ & \multirow{2}{*}{.062} & & $\begin{array}{l}5 \\
(16.7)\end{array}$ & $\begin{array}{l}6 \\
(20.0)\end{array}$ & $\begin{array}{l}19 \\
(63.3)\end{array}$ & & & $\begin{array}{l}5 \\
(16.7)\end{array}$ & $\begin{array}{l}12 \\
(40.0)\end{array}$ & $\begin{array}{l}13 \\
(43.3)\end{array}$ & & \\
\hline & No & $\begin{array}{l}n \\
(\%)\end{array}$ & $\begin{array}{l}123 \\
(42.0)\end{array}$ & $\begin{array}{l}85 \\
(29.0)\end{array}$ & $\begin{array}{l}85 \\
(29.0)\end{array}$ & & & $\begin{array}{l}58 \\
(19.8)\end{array}$ & $\begin{array}{l}110 \\
(37.5)\end{array}$ & $\begin{array}{l}125 \\
(42.7)\end{array}$ & & 5.554 & $\begin{array}{l}66 \\
(22.5)\end{array}$ & $\begin{array}{l}82 \\
(28.0)\end{array}$ & $\begin{array}{l}145 \\
(49.5)\end{array}$ & .352 & 2.089 & $\begin{array}{l}71 \\
(24.2)\end{array}$ & $\begin{array}{l}139 \\
(47.4)\end{array}$ & $\begin{array}{l}83 \\
(28.3)\end{array}$ & .218 & 3.046 \\
\hline
\end{tabular}

* Separate analysis was performed for each question type and then results combined as a single table.

** 1: 'Descriptive questions', 2: 'Affective questions', 3: 'Questions on objectives', 4: 'Questions associated with daily life' 
In Table 3, "descriptive questions" are seen to always be preferred by teachers who had received training or attended seminars in order to maximize the children's skills with a ratio $46.7 \%$, and mostly by $37.7 \%$ of teachers who had not. For this aim, both trained and non-trained teachers mostly have a tendency to use "affective questions." In addition, $63.3 \%$ of the teachers who had attended seminars or training always preferred "questions associated with daily life," while the non-trained teachers preferred this question type occasionally with a rate of $19.8 \%$. According to the results of the Chi-Square Tests, no significant difference was found between the teachers' frequency usage of evaluation questions and having received training on the evaluation of young children: $\chi 2$ (SD $=2, \mathrm{n}=323)=4,567 ; \chi^{2}(\mathrm{SD}=2, \mathrm{n}=323)=5,370 ; \chi^{2}(\mathrm{SD}=2, \mathrm{n}=323)=6,806$ and $\chi 2(\mathrm{SD}=2, \mathrm{n}=323)=$ $5,554, \mathrm{p}>.05$.

It can be concluded that approximately $50 \%$ of the teachers always used "descriptive questions," "affective questions," "questions on objectives" and "questions associated with daily life" by taking into account the developmental characteristics of the children for developmental follow-up, irrespective of whether or not the teachers had been trained on the evaluation of young children. Although the majority of the teachers used these assessment questions for this purpose, there was no significant difference found between the usage frequency of evaluation questions and the teachers' seminar/ training status; $\chi 2(\mathrm{SD}=2, \mathrm{n}=323)=2.71 ; \chi 2(\mathrm{SD}=2, \mathrm{n}=323)$ $=2.17, \chi^{2}(\mathrm{SD}=2, \mathrm{n}=323)=.50$ and $\chi 2(\mathrm{SD}=2, \mathrm{n}=323)=2.09, \mathrm{p}>.05$.

Finally, the teachers who had attended training or seminars on the evaluation of young children always preferred "descriptive questions" with the ratio of $43.3 \%$ when making end-of-day assessments, while $48.1 \%$ of the non-trained teachers occasionally used these questions. Moreover, $43.3 \%$ of the trained teachers always asked "questions associated with daily life" in their classroom; whilst the non-trained teachers just occasionally preferred these questions with the ratio $24.2 \%$ to assess children at the end of the day. As a result, no significant difference was found between the usage frequency of both "affective questions" and "questions associated with daily life," and having received any training on the evaluation of young children; $\chi 2(\mathrm{SD}=2, \mathrm{n}=323)=2.78$ and $\chi^{2}(\mathrm{SD}=$ $2, \mathrm{n}=323)=3.05, \mathrm{p}>.05$.

\section{Discussion and Conclusion}

This study examined which types of evaluation questions are preferred by early childhood teachers for the preparation and the implementation of activity plans, and whether or not the usage frequency of evaluation question types changes based on teachers having received or not received training or attended seminars on the evaluation of young children. For this study, teachers' feedback was sought on question types stipulated in the program evaluation of Turkey's National Preschool Education Program, which are "descriptive questions," "affective questions," "questions on objectives," and "questions associated with daily life," and the results analyzed individually for each type.

As a result of this research, it was seen that the preschool teachers primarily preferred "descriptive questions" rather than "questions on objectives," and rarely used "questions associated with daily life" for the evaluation of young children playing in different learning centers. This result parallels the results of other studies that concluded that teachers prepare and ask low-level questions and closed questions during the assessment process (Bay, 2016; Baysen, 2006; Lee, 2010; Storey, 2004). The reason for this result could be that teachers prepare questions to be answered at the 'remember' level instead of open-ended questions which need to be revised according to changing dynamics of the learning center. Preparing questions at the knowledge level and obtaining answers requires a shorter timeframe and the responses will be more observable. Teachers may therefore prefer questions based on memorization and knowledge repetition because they are more practical to administer and require less occupational knowledge. As Büyükalan (2002) stated, when individuals learn more, they can ask high-level questions; and therefore, if teachers advance their own questioning skills, they may have at hand a variety of questions to ask in different environments and for different individuals. In addition, Vogler (2005) emphasized that teachers should know the features of question asking and should be willing to implement them and to ask more questions. As seen in the results of the current study, teachers will be familiar with different types of questions and will also be seen as a model for children if they ask questions both during the teaching process and also in their daily life. In parallel with other findings of the study, for children working at different learning centers, a significant difference was seen between the usage frequencies of "affective questions" for teachers who had received some form of training on the evaluation of young children. It was found that trained teachers asked more "affective questions" than nontrained teachers. This result showed that when teachers advance their skills through training or attending seminars, 
they could help children to think in a more creative and critical manner through the application of different evaluation question types for different learning centers. In addition, with training, teachers can prepare and ask more concrete questions that are associated with children's life experiences, include familiar words for children and be prepared through current events and objects. As stated by Massey et al. (2008), the inclusion of more questions in the education process by teachers results in gaining the support of children's participation, and also that questions that are formed differently for various learning centers may result in more complex and detailed responses by the children.

According to another result of the study, teachers used "questions on objectives" instead of "questions associated with daily life" and "affective questions" in order to maximize the skills of children. This is seen as a remarkable result, that while the target was to maximize the skills of children, only $10 \%$ of the preschool teachers preferred to use "questions associated with daily life" that support high-level thinking ability. The reasons for not preferring to ask open-ended questions that help children to think creatively could be noted as a fear of asking the right questions and/or not being able to respond adequately to the children's questions. In this context, the lack of any specific course targeted at supporting teachers' questioning skills in undergraduate education, and the lack of lessons related to the subject, could lead to the inability of teachers to fully support their questioning skills. Additionally, the preparation and attendance to specific courses or training on child evaluation to support questioning skills may not be sufficient for teachers to gain such skills at a comprehensive level. In the published research, it is seen that children's potential can be enhanced and developmental progress observed when preschool teachers have sufficient training and education to gain high quality questioning skills (Barnette, Orletsky, \& Sattes, 1994; Büyükalan Filiz, 2007; Storey, 2004; Zeegers \& Elliott, 2018). Moreover, the reason why teachers prefer memorization questions to open-ended questions could be stated as teachers needing more time in the classroom. As, when open-ended question are addressed to children; new questions could arise, teachers may have to move away from the main objective and focus on a non-targeted issue, and the teacher may be concerned over resultant issues of class management (Chin \& Osborne, 2008). In parallel with this result, Waterhouse (1990) stated that if more time is needed to answer the questions and teachers ask questions to only a few children; in this case, the children stop being involved in the activity and classroom management problems can be observed.

According to another result of the current study, the teachers stated that they used the four types of assessment questions stated in the Ministry of National Education program with a balanced distribution for developmental follow-up, considering the developmental characteristics of children. However, in the second step of the study, no significant difference was found between the usage frequencies of evaluation questions and having received training or attended seminars on the evaluation of young children. This may be due to prospective teachers' undergraduate education about the importance of the "whole child" and assessment of overall development of children on their courses. In addition, in the undergraduate teacher training program, general assessment was taught rather than specific courses related to questions and questioning; therefore, this could have had an effect on the issues of training on evaluation making no difference to the usage frequency of evaluation questions.

In another finding, it was determined that teachers preferred "questions on objectives" to "affective questions" for end-of-day assessment of education. This preference could be due to observable consequences and answers of "questions on objectives" in their daily routine. Therefore, preschool teachers could easily complete the objectives control list. This result is in line with the work of Carin, Bass, and Contant (2005). In Carin et al.'s (2005) study, it was determined that teachers preferred closed questions in order to determine the reflection of teaching on children in a comfortable way and to be able to observe the skills of children through the application of closed questions. Thus, it was stated that teachers could make a more comfortable evaluation on the answers of the children. On the other hand, when the relationship between the usage frequency of evaluation questions and having received training or attended seminars on evaluation was examined, there was a meaningful relationship found between having attended training and the usage frequency of both "descriptive questions" and "questions on objectives." This result can be interpreted as when teachers attend training or seminars on the evaluation of young children, they could learn which question types to use for both the process and end-of-day assessment. In the current study, it was determined that the teachers preferred more questions at knowledge level, for instance "descriptive questions" and "questions on objectives" for the end-of-day assessment, while for process evaluation these question types were used occasionally or mostly by preschool teachers. 
Many researchers have emphasized that the quality of teachers is of significant importance and impacts on the development of children, especially in the preschool period (Burchinal, 2018; National Institute of Child Health and Human Development Early Child Care Research Network, 2002, 2005; Smolensky \& Gootman, 2003). Questions and answers within the evaluation process, which is considered an important part of education, can be used as a rich tool in order to define assumptions, to reveal contradictions and to reach new information. When teachers reflect on their children that questioning skills are worth modeling, children will themselves make new discoveries by questioning as well. When children ask more questions in the process, education becomes more effective and interesting (Kaya \& Elgun Ceviz, 2017); therefore children's thinking skills should be supported (King, 2005) so that children's own questioning will shape subsequent activities and increase their motivation (Chin \& Osborne, 2008). In addition, questioning skills will help children to analyze subjects and events, to solve problems, to adapt to change and thus to identify new opportunities and move towards new directions. In this context, the first step of a teacher who focuses on solutions rather than problems should be to ask questions, because where there are no questions, therein lies the problem. Teachers should always ask themselves this question, "What could I ask the children?" and should always think about what children could be asked these questions. For this purpose, teachers should continue to be good listeners and observers of children. The fact that teachers see questions as the most important tool that will guide and extend communication in the classroom (Yang, 2006), therefore should be an indication of how much teachers should care about their questioning skills in education.

According to the literature review, studies about evaluation questions focus on the structure of questions (e.g., open-ended, closed) or their cognitive level (remember, understand, apply, analyze, evaluate, create). On the other hand, the current study specifically targeted evaluation questions recommended for preschool teachers in the MoNE early childhood education program. The specific focus was on teachers" usage of "descriptive questions," "affective questions," "questions on objectives" and finally "questions associated with daily life." It is considered that this study will contribute to the literature in terms of providing feedback on evaluation questions used in oneto-one practices in Turkey. However, the study data were limited to the survey conducted online and 323 teachers' opinions. For the following study, if the study is carried out with more preschool teachers all over the Turkey, the generalizability of the data about the evaluation questions preference of teachers may increase. Moreover, the questionnaire consists of likert-type questions therefore teachers' opinions on evaluation questions are limited by quantitative data. In order to handle such limitation in the following studies, a qualitative study on the use of these assessment questions and the reasons of the preferences of the teachers and the possible consequences of their preferences can be discussed. In addition, another study can be carried out to compare the views of teachers and the opinions of policy makers on preschool education in relation to assessment questions. As a result of such study, there could be a general picture of the views on to what extent and how the planned policies could be implemented or not about assessment questions in preschool education. Such a reflection is expected to provide a rich feedback for the evaluation of the training program being implemented in Turkey. In addition, providiOng trainings and workshops about especially pre-school assessment and effective questioning for both pre-school teacher candidates and teachers, will allow them to make self-assessments about questioning. In addition, for both researchers and field practitioners, it may be recommended to prepare an online training or practice which can be prepared by planning on sample cases. With such an application, teachers will be able to learn how to prepare different types of questions in different case situations, and gain the ability to ask questions. 


\title{
Okul Öncesi Eğitim Programının Değerlendirme Sorularının Kullanımına Yönelik Öğretmen Görüşleri
}

\begin{abstract}
Giriş
Çocuğun sağlıklı bir şekilde büyüyebilmesi, gelişebilmesi ve öğrenebilmesi; bütüncül gelişimi destekleyecek bir eğitimin çocuğa sunulmasıyla gerçekleşebilir. Bu eğitim gelişimsel olarak uygun bir program dâhilinde hazırlandığında, çocukların bireysel farklılıkları temel alınarak tüm gelişim alanlarında boylamsal bir takip firsatı yakalanabilir. Bu takibin yapılabilmesi için de programın değerlendirmesi bu programın vazgeçilmez parçası olarak ele alınır. Programa dâhil edilecek olan değerlendirme, çocukların eğitim süreçleri ile ilgili fikir üretebilmek ve karar vermek için çocuğa, aileye, öğretmene, okula gerekli bilgiler sağlayabilir. Programın ve öğrenmenin değerlendirilmesi için okul öncesi dönemde standart testlere ek olarak alternatif değerlendirme yöntemleri de tercih edilmektedirler. Araştırmacılar ve eğitimciler 'özgün' değerlendirmeyi standart testlere umut verici bir alternatif olarak tanımlamaktadır (Bricker, Pretti-Frontczak, Johnson, \& Straka, 2002; Downs \& Strand, 2006). Söz konusu özgün değerlendirme ile öğretmen çocukları bireysel olarak süreç içerisinde onların birebir katılımı ile değerlendirebilir ve onlara destek olabilir. Öğretmen aynı zamanda sınıf atmosferi ve çocukların ihtiyaçlarına yönelik alternatif değerlendirme yöntemlerinden gözlem, soru sorma, görüşme gibi en uygun teknikleri tercih ederek verimli bir geribildirim sağlayabilir.

Soru sorma çok uzun yıllardır eğitimde kullanılan önemli bir yöntem olarak tercih edilirken, etkinliklerin vazgeçilmez ve en etkin parçasını oluşturmaktadır (Muijs \& Reynolds, 2005; Tan, 2007). Üretilebilen iyi bir soru, eğitimin en etkili aracı olurken, iyi öğretmen de en büyük etkiyi yaratabilmek için bu soruları nasıl kullanması gerektiğini bilen kişi olarak düşünülmektedir (MyHill \& Dunkin, 2002). Soru, bir kişinin düşünmesini ya da bilgi elde etmesini amaçlamak için hazırlanan bir cümle (MacNaughton \& Williams, 2004) olarak tanımlanırken, öğretmenler soruları eğitim sürecine birçok amaçla kullanabilmektedir. Bu amaçlar; dikkat çekmek, üst düzey düşünme becerilerini desteklemek, duyguları ifade etmek ve yeniden yönlendirmek (Borich, 2013), çocukların önyargılarını ve yanlış bildiklerini belirlemek, tartışmaları çözümlemek, eski ile yeni kavramlar arası köprü oluşturmak, farklı içerikte yeni bilginin kullanımını desteklemek (Yip, 2004), sınıf içi tartışmaları başlatmak (Nassaji \& Wells, 2000), çocukların öğrendiklerini değerlendirmek (Petty, 1993), çocukların etkinliklerini tamamlamalarına yardımcı olmak (Erdoğan \& Campbell, 2008) gibi çok çeşitli şekilde sıralanabilmektedir.

Eğitimde yer verilen soru kullanımı birçok çalışmacı tarafindan "doğru", "gerekli", "üretici", "rehber", "verimli" olmak üzere farklı şekilde tanımlanmıştır (Kohn, 2015). Rehber niteliğinde olabilecek sorular Bloom'un 1956 yılında oluşturmuş olduğu taksonomisine göre altı basamakta sıralanmış ve bunlar bilgi, kavrama, uygulama, analiz, sentez ve değerlendirme olarak belirtilmiştir (Cecil \& Preifer, 2011). Bu taksonomi 1999 yllında Lorin Anderson ve meslektaşları tarafindan öğrenme ve öğretme üzerinde daha fazla faktörün etkili olduğu düşüncesiyle güncellenmiştir (Yurdakan, 2012). Güncellenen taksonomi 'bilgi' ve 'bilişsel süreçler' olmak üzere iki boyut olarak ele alınmıştır. Bilgi boyutu, "olgusal, kavramsal, işlemsel ve bilişüstü bilgi" olarak sınıflandırılırken; bilişsel süreçler boyutu "hatırlama, anlama, uygulama, analiz etme, değerlendirme ve yaratma" ş̧eklinde yine altı adımda sınıflandırılmıştır (Krathwohl, 2002). Bilişsel boyutun ilk adımı olan hatırlamada zihinde olan doğru bilgiyi getirme söz konusudur. Burada düşünme ve yorumdan ziyade ezberlenen bilgiler odaklı sorular üretilmektedir. Eğitim materyalleri ve deneyimlerden anlam oluşturmanın temel olduğu anlama basamağındaki sorularda 'bul', 'karşılaştır', 'açıkla', 'özetle' ifadelerine yer verilmektedir. Üçüncü sıradaki uygulama basamağında, verilen bir durumda uygun işlemi kullanma veya uygulama vardır. Bir kavramı parçalarına ayırma ve bu parçaların bütün ile nasıl bir ilişkisinin olduğunun keşfedilmesi analiz basamağında gerçekleşirken, değerlendirme basamağında kontrol ederek ve eleştirerek standartlara dayalı yargılar oluşturulmaktadır. Bloom'un güncellenen taksonomisinin son basamağında ele alınan yaratma ise çocuğun yeni bir şey oluşturmak için parçaları bir araya getirme becerisini içermektedir. Analiz, değerlendirme ve özellikle yaratma basamakları ise üst düzey soruların ele alındığı basamakları oluşturmaktadır. Bu düzeylerde bireylerin yaratıcı ve eleştirel düşünme becerileri desteklenerek kendi yargılarını oluşturmaları hedeflenmektedir. Eğitim süresinde ele alınması planlanan sorular Bloom'un güncellenen taksonomisinde yer alan bilişsel süreçler boyutuna ve çocukların gelişim düzeylerine uygun olarak hazırlanmalıdır (Storey, 2004). Buna ek olarak alanyazın incelendiğinde eğitimde de sıkça kullanılan sorular yapıları temel alınarak, kapalı uçlu sorular ve açık uçlu sorular olarak iki ana başlık altında incelenmektedir. Kapalı uçlu sorular, bilgi düzeyinde kısa cevaplar gerektirirken, açık uçlu sorular çocuğu düşünmeye ve fikirlerini aktarmaya yöneltecek uzun ve açıklayıcı cevapları beraberinde getirmektedir (Bay, 2016; MacNaughton \& Williams, 2004).
\end{abstract}


Yapılan araştırmalar öğretmenlerin kullandıkları soru yapılarını çok sınırlı görmekte ve öğretmenlerin çoğunlukla kapalı uçlu soruları ve doğrudan bilgi sorularını tercih ettiklerini belirtmektedir (Bay \& Hartman, 2015; Meacman, Vukelich, Han \& Buell, 2014; Storey, 2004). Öğretmenlerin eğitim sürecinde çocuklara yönelttikleri sorular; çocuklara, ne bildikleri ve neyi sorgulamaya ihtiyaç duyduklarını kendi düşünceleri aracılığıyla yansıtma firsatı sunmaktadır (Fisher, 1995). Bu yüzden yaratıcı ve açık uçlu sorular eğitim süresince öğretmenlerin en önemli araçları kabul edilebilmektedir. Ancak yaratıcı sorular hazırlayabilmek eleştirel düşünme becerisi ve önemli kaynaklara ihtiyaç duymasından dolayı (McComas \& Abraham, 2005) bu soruları üretmek yer yer zaman kaybı gibi görülebilmektedir. Bu sebeple öğretmen çocukların ihtiyaçları ve hedeflenen kazanımlar doğrultusunda çalışmalarını şekillendirirken, sorularını da dikkatli bir şekilde önceden belirlemelidir. Çünkü etkili soru sorma, çocukların bilgisini kontrol etmekten ziyade onların öğrenmelerini desteklemekte (MacNaughton \& Williams, 2004; Vogler, 2005), onların eleştirel düşünme, karar verme ve problem çözme becerilerinin gelişmesine olanak sağlamaktadır (Sellappah, Hussey, Blackmore \& McMurray, 1998). Ayrıca öğretmenler tarafindan hazırlanacak sorularda neden, nasıl gibi (Sen nasıl...?, Neden...düşündün?) soru kalıpları kullanılması, çocukların anlamaları, hayal kurmaları, hissetmelerini sağlarken, onların kendi deneyimlerini yeniden düşünebilme imkanı sunmaktadır (MacNaughton \& Williams, 2004). Tercih edilecek sorulardaki çeşitlilik, çocukların yanıtlarının güçlük ve karmaşıklık düzeyini destekleyerek artıracaktır (Massey, Pence, Justice \& Bowles, 2008). Ek olarak, bilişsel olarak çocukları zorlayacak sorular, onların sınıf içinde kendilerini fark etmelerine destek olacak, etkinliklere katılımlarını artıracak ve derin öğrenmelerine yol açacaktır (Zeegers \& Elliott, 2018). Ancak eğitim ve değerlendirme sürecinde ister kapalı uçlu ister açık uçlu soru olsun, çocuklar soru içermeyen düz yorumlara ya da ifadelere soru içeren konuşmalardan daha az tepki vermektedirler (Meacman vd., 2014). Bu sebeple öğretmenler değerlendirme de dâhil olmak üzere eğitimin her basamağında sorulara her zaman yer vermeleri gerekmektedir. Ayrıca öğretmenlerin soru sorarken amaçlarını, soruların çeşitlerini, ne zaman hangi soruları tercih etmeleri gerektiğini iyi belirlemeleri gerekmektedir. Öğretmenlerin, alt düzey soruları çocuğun güçlü ve zayıf yanlarının neler olduğunu belirlemek ve bunların değerlendirmesini yapmak üzere; üst düzey soruları da çocuğun eleştirel düşünme ve problem çözme becerilerini desteklemek amacıyla hazırlamaları gerektiğini her zaman bilmeleri beklenmektedir (Bay, 2016; Storey, 2004).

Eğitim ve özellikle değerlendirme sürecinde gerekliliği vurgulanan sorular okul öncesi eğitim programları içerisinde de yerini almaktadır. Türkiye'de kullanılan Milli Eğitim Bakanlığı (MEB) Okul Öncesi Eğitim Programı değerlendirme sürecinin çok yönlü olması gerektiğinin üzerinde dururken, temel ilkelerinde 'değerlendirme sonuçları çocukların, öğretmenin ve programın geliştirilmesi amacıyla etkin olarak kullanılmalıdır' şeklinde yer almaktadır (MEB, 2013, s.13). Eğitim sürecinin önemli bir parçası kabul edilen değerlendirme, okul öncesi eğitim programında ayrı bir başlık altında detaylı bir şekilde ele alınmıştır. Bu bölümde, çocukların ve öğretmenlerin değerlendirilmesine ek olarak program değerlendirilmesinin yapılabilmesi için etkinlik sürecinde kullanılmak üzere öğretmenlere yol gösterici sorular belirlenmiştir. Bu sorular "Betimleyici, Kazanım ve Göstergelere Yönelik, Duyuşsal ve Yaşamla İlişkilendirme Soruları" olmak üzere dört ana başlık altında ele alınmıştır (MEB, 2013). Betimleyici sorular değerlendirmenin ilk aşaması olarak görülmekte ve etkinlikle ne yapıldığının açıklanmasına yardımcı olmaktadır. Kazanımlara ve göstergelere yönelik sorular, etkinlik planındaki hedeflere ne kadar ulaşılıp ulaşılmadığını belirlemek için değerlendirme sürecinde yer almaktadır. Duyuşsal sorularla çocukların etkinlik sürecinde ne hissettikleri ile görüş paylaşmalarına firsat tanınırken, yaşamla ilişkilendirme sorularında çocukların etkinlikte yaşanılanlarla kendi yaşamları arasında bir ilişki kurabilmelerine imkân sağlanmaktadır. Programda öğretmenlere rehberlik etmesi açsından bu soruların örneklerine yer verilmektedir. Betimleyici soruları ne, nerede, kim soruları odaklı hatırlama soruları içerirken, kazanımlara yönelik sorular anlama ve uygulama düzeyinde çocukların etkinlik kapsamında hedeflenen kazanımları ne kadar edinip edinmediği odaklı sorulardır. Duyuşsal sorularda çocukların kendileri ve başkalarının duygularını kavrama ve gerektiği noktada analiz ederek yorumlamalarına firsat tanınmaktadır. Son olarak yaşamla ilişkilendirme sorularında amaç çocukların öğrendiklerinin kalıcılıklarını sağlamaktır. Bu sorular çocukların etkinlik sürecini kavradıktan sonra kendi yaşamıyla da ilişkilendirerek analiz etmelerine, değerlendirme yaparak yeni yapılar oluşturmalarına yardımcı olacak sorular olarak etkinlikler devam ederken ve etkinliklerin sonunda çocuklara yönlendirilmektedir.

Belirlenen bu soruların öğretmenlere etkinlik hazırlama ve uygulama aşamasında yol gösterici olması hedeflenmiş olsa da uygulamada okul öncesi dönemde değerlendirme süreci gereken dikkati üzerine çekememektedir. Yapılan çalışmalara bakıldığında da okul öncesi eğitiminde kullanılan değerlendirme sorularından daha çok hangi değerlendirme yöntemlerinin tercih edildiği ve çalışmalarda bu yöntemlere yönelik 
öğretmen görüşlerine yer verildiği görülmüştür (Buldu, 2010; Dennis, Rueter \& Simpson, 2011; Can Gül, 2009; Hanes, 2009; Kaya, 2018; Turupcu, 2014). Bu çalışmada ise okul öncesi dönem değerlendirme yöntemlerinden daha özelleşilerek, öğretmenlerin değerlendirme sürecinde tercih ettikleri soruları ve kullanım sıklıklarına dikkat çekilmesinin önemli olduğu düşünülmüştür. Çünkü öğretmenlerin değerlendirme süreçlerinde çoğunlukla alt düzey sorular ve kapalı uçlu soruları tercih ettikleri yapılan çalışmalarda görülmektedir (Bay, 2016; Baysen, 2006; Lee, 2010; Storey, 2004). Bu çalışma yürütülürken okul öncesi eğitim değerlendirme süresi için; 'çocukların farklı merkezlerde cevaplayabilecekleri şekilde soruları hazırlama', 'çocukların becerilerini üst düzeye çıkarabilecek nitelikte sorular hazırlama', 'gelişim takibi amacıyla gelişim özellikleri dikkate alınarak sorular sorma' ve 'sorularla gün sonu değerlendirme yapma' şeklinde 4 hedef belirlenmiştir. Bu çalışma, MEB okul öncesi eğitim programında kullanılan betimleyici, kazanımlara ve göstergelere yönelik, duyuşsal ve yaşamla ilişkilendirme değerlendirme sorularının hangilerinin daha çok tercih edildiği ve belirlenen hedefler doğrultusunda ne sıklıkta kullanıldığına yönelik farklı bir bakış açısı sunması açısından önemlidir. Çünkü öğretmenler hangi soruları ne kadar sıklıkla tercih ettikleri ile ilgili bir farkındalık kazandıklarında, çocuklara daha uygun sorular yöneltebilecek ve onların da soru sormalarını teşvik edebilecektir. Bunun sonucunda da çocukların anlama becerileri desteklenebilecek (Nystrand, Wu, Gamoran, Zeiser \& Long, 2003) ve etkinlikler sürecinde devam eden karş1lıklı konuşmalar ve sorularla birlikte çocuklar kendilerini daha değerli ve motive olmuş hissedeceklerdir (Mercer \& Howe, 2012). Bu çalışma da öğretmenlerin Türkiye'deki okul öncesi eğitim programında kullanılması önerilen değerlendirme sorularının kullanım durumu ile ilgili genel resmi görebilmeleri açısından önemlidir. Çünkü eğitimde yer verilen sorularla birlikte çeşitli görüşlerin değerlendirilmesi için farklı tartışılma ortamlarının oluşmasına olanak sağlanacaktır. Böylece çocukların eleştirel düşünme ve problem çözme becerilerinde daha da ilerleme olabilecektir (Günel, Kıngır \& Geban, 2012; Mercer \& Howe, 2012; Scott, Mortimer \& Aguiar, 2006).

Söz konusu çalışmada, okul öncesi öğretmenlerinin çocukların eğitimlerinin değerlendirilmesi süresinde belirledikleri hedeflere ulaşmak için tercih ettikleri değerlendirme sorularıyla ilgili geribildirimleri ile aşağıdaki soruların yanıtlanması amaçlanmıştır;

1- Okul öncesi öğretmenleri betimleyici soruları, kazanım ve göstergelere yönelik soruları, duyuşsal sorular ve yaşamla ilişkilendirme değerlendirme sorularından hangilerini okul öncesi eğitim programı dâhilinde tercih etmektedir?

2- Okul öncesi öğretmenlerinin tercih ettikleri değerlendirme sorularını kullanma sıklıkları, değerlendirme ile ilgili seminer/ eğitim alma durumlarına göre anlamlı bir fark göstermekte midir?

\section{Yöntem}

Bu bölümde araştırma modeli, örneklem, veri toplama araçları, veri toplama süreci ve verilerin analizine yer yerilmektedir.

\section{Araştırmanın Modeli}

$\mathrm{Bu}$ araştırmada okul öncesi eğitim kurumlarında çalışan öğretmenlerin eğitim programlarında kullandıkları değerlendirme sorularını kullanım sıklıklarına ilişkin görüşlerini, daha geniş kitledeki öğretmenlere ulaşarak elde etmek istenildiğinden nicel araştırma yöntemlerinden tarama modeli tercih edilmiştir. Tarama araştırmalarında daha geniş bir topluluğun görüşleri ele alınırken, verilerin bu kişilere yöneltilen sorulara verilen cevaplarını içermesi gerekmektedir (Fraenkel \& Wallen, 2006). Ayrıca bu çalışmalarda katılımcıların belirttikleri görüşlerinin nedenleri yerine katılımcıların gözünden nasıl bir dağılım gösterdiğine odaklanılmaktadır. Bu çalışmada da öğretmenlerin eğitim sürecinde okul öncesi eğitim programında yer alan değerlendirme sorularını etkinliklerini hazırlama ve uygulama aşamasında ne tür bir dağılım takip ederek kullandıklarının belirlenmesi hedeflenmiştir.

\section{Örneklem}

Çalışmanın örneklemi oluşturulurken amaçsal örneklem türü olan maksimum çeşitlilik örnekleme tercih edilmiştir. Bunun sebebi belirlenen problem doğrultusunda farklı örneklemler ele alınarak genelleme kaygısı olmaksızın evren hakkında belirli ipuçları elde edebilmektir (Büyüköztürk, Kılıç Çakmak, Akgün, Karadeniz, \& Demirel, 2014). Ayrıca belirlenen amacın yanı sıra farklı durumlar içerisindeki benzer ya da farklı yönler ortaya konulması problemi farklı açılardan da değerlendirebilme imkânı sunabilmektedir. Bu çalışmanın örneklemini Türkiye'nin farklı illerinde görev yapan 323 okul öncesi öğretmeni oluşturmaktadır. Tablo 1 'de bu öğretmenlere ilişkin demografik bilgilere yer verilmiştir. 
Tablo 1'de okul öncesi öğretmenlerinin yaş, cinsiyet, öğrenim durumu, mezun oldukları bölüm, mesleki kıdem, çalıştıkları yaş grubu, çalıştıkları sınıf mevcudu ve değerlendirme ile ilgili seminer alma durumlarına göre dağılımı görülmektedir.

Tablo 1. Okul Öncesi Öğretmenlerine İlişkin Demografik Bilgilerin Dağılımı

\begin{tabular}{|c|c|c|c|}
\hline & & $\mathrm{F}$ & $\%$ \\
\hline \multirow{3}{*}{ Yaş } & $21-30$ & 165 & 51.1 \\
\hline & $31-40$ & 114 & 35.3 \\
\hline & 41 ve üzeri & 44 & 13.6 \\
\hline \multirow{2}{*}{ Cinsiyet } & Kadın & 299 & 92,6 \\
\hline & Erkek & 24 & 7.4 \\
\hline \multirow{2}{*}{ Öğrenim durumu } & Lisans & 262 & 81.1 \\
\hline & Diğer (Meslek Lisesi, önlisans, lisans tamamlama) & 61 & 18.9 \\
\hline \multirow{2}{*}{ Mezun olunan bölüm } & Okul Öncesi Eğitimi & 232 & 71.8 \\
\hline & Diğer (Çocuk gelişimi/ ve eğitimi) & 91 & 28.2 \\
\hline \multirow{4}{*}{ Mesleki kıdem } & $0-5$ yil & 134 & 41.5 \\
\hline & $6-10 \mathrm{y} 1 \mathrm{l}$ & 102 & 31.6 \\
\hline & $11-15 \mathrm{y} 1 \mathrm{l}$ & 47 & 14.6 \\
\hline & 16 ve üzeri & 40 & 12.4 \\
\hline \multirow{3}{*}{ Çalışılan yaş grubu } & 3-4 yaş & 87 & 26.9 \\
\hline & 5 yaş & 161 & 49.8 \\
\hline & 6 yaş & 75 & 23.2 \\
\hline \multirow{3}{*}{ Çalışılan sınıf mevcudu } & $10-15$ çocuk & 119 & 36.8 \\
\hline & $16-20$ çocuk & 125 & 38.7 \\
\hline & 21 ve üzeri & 79 & 24.5 \\
\hline \multirow{2}{*}{ Seminer alma durumu } & Evet & 30 & 9.3 \\
\hline & Hayır & 293 & 90.7 \\
\hline
\end{tabular}

Örnekleme genel olarak bakıldığında, öğretmenlerin yarısının 21-30 yaş aralığında olduğu ve \%92 sinin kadın olduğu belirlenmiştir. Öğretmenlerin \%81'i lisans programlarından mezunken, \%71.8'lik kısım okul öncesi eğitimi/ öğretmenliği bölümünden mezun olmuştur. Öğretmenlerin \%41.5'i meslek hayatlarının ilk beş yılında iken, öğretmenlerin yaklaşık yarısı 5 yaş grubu çocuklarla çalışmakta olup öğretmenlerin yaklaşık \%25'i görev yaptıkları sınıfın mevcudunu 21 ve üzeri olarak belirtmiştir. Son olarak da örneklemdeki öğretmenlerin \% $\% 0.7$ gibi büyük bir çoğunluğu okul öncesi eğitimde değerlendirme ile ilgili bir seminere katılmamıştır.

\section{Veri Toplama Araçları}

Bu çalışmada veri toplama aracı olarak öğretmenlerin değerlendirme sorularını kullanımlarına ait görüşlerini betimlemelerini hedeflenmiştir. Araştırma materyali olarak anket tercih edilmiştir. Daha büyük gruplara daha kısa sürede ve daha az maliyetle ulaşılması açısından avantaj sağlayan ankette katılımcıların anket maddelerine samimi bir şekilde yanıt verdikleri temel sayıltı olarak ifade edilmektedir (Büyüköztürk vd, 2014).

Anket iki bölümden oluşmakta olup ilk bölümde katılımcıların demografik özelliklerini betimlemek için kullanılan olgusal sorulara yer verilirken, ikinci bölüm de ise katılımcıların okul öncesi eğitimde kullanılan değerlendirme sorularına ilişkin görüşlerinin belirlenmesi için inanç ve kanı soruları olarak adlandırılan sorulara ver verilmiştir. Anket geliştirme sürecinde okul öncesi eğitimde değerlendirme ve süreçte kullanılan değerlendirme soruları ile ilgili literatür incelenerek hedefe yönelik sorular hazırlanmıştır. Bu sorular değerlendirme sorularını hazırlama ve uygulama olmak üzere iki temel başlık altında taslak halde sıralanmıştır. Hazırlanan taslak form, amaç, kapsam, içerik, dil ve gelişim düzeyine uygunluk kriterleri açısından değerlendirilmek üzere iki okul öncesi eğitimi ve bir ölçme ve değerlendirme alan uzmanına gönderilmiştir. Alan uzmanlarından alınan geribildirimler doğrultusunda soruların anlam bütünlüğünü bozan anlatım bozuklukları 
düzenlenmiştir. Daha sonra, belirlenen örneklem büyüklüğünün \%20’si kadar katılımcıya öntest uygulanması yeterli kabul edildiği (Büyüköztürk vd, 2014) için, 67 okul öncesi öğretmeni ile ön uygulama yapılmıştır. Geçerlik ve güvenirliği desteklemek için yapılan bu hazırlıklardan sonra anket maddelerinde anlaşılmayan üç madde çıkarılmış ve maddelerin soruş sırasında güncelleme yapılmıştır.

Nihai anket formunun ilk bölümde öğretmenlerin demografik bilgilerine ikinci bölümde ise öğretmenlerin görüşlerini almak adına on üç maddeye yer verilmiştir. Katılımcıların belirtilen her bir soruyu yanıtlarken Milli Eğitim Bakanlığı (MEB) Okul Öncesi Eğitim Programında yer verilen 4 çeşit değerlendirme sorusunu (betimleyici, duyusşal, kazanım ve göstergelere yönelik ve yaşamla ilişkilendirme soruları) göz önünde bulundurarak cevaplamaları beklenmiştir (MEB, 2013). Hazırlanan sorular, öğretmenlerin bu değerlendirme sorularını kullanma sıklıklarına yönelik 5li likert form düzeninde oluşturulmuştur.

\section{Verilerin Toplanması}

Anketi uygulama süresince katılımcıların büyük çoğunluğuna çevrimiçi oluşturulan anket formu ile ulaşılmıştır. Ayrıca Ankara'da yüz yüze görüşme ile de öğretmenlere ulaşılmış ve anket formu uygulanmıştır. Çevrimiçi olarak hazırlanan anket formu ile daha fazla katılımcıya ulaşılmıştır. Verilerin kalitesi açısından bazı anketler analiz dışı bırakılmış ve neticesinde toplamda 323 anketle analiz gerçekleştirilmiştir.

\section{Veri Analizi}

Söz konusu çalışmada nicel araştırma yöntemi tercih edilmiş olup, veriler anket yoluyla toplanmıştır. Bu sebeple parametrik olmayan istatistiklerden iki değişken için kay-kare Testi (Chi-Square Test $\chi^{2}$ ) kullanılarak veri analizi gerçekleştirilmiştir. Tarama çalışmalarında sıklıkla kullanılan bu testle iki kategorik değişken arasındaki ilişkinin olup olmadığını belirlemek amaçlanmaktadır. Kay- kare testinde beklenen değeri 5 'ten küçük gözenek sayısının \%20’yi aşması durumunda üç farklı çözüm yolu sunulmaktadır. Bunlardan birisi mantık çerçevesinde ilgili satır ya da sütunda birleştirmeye gitmektir. Burada amaç gözeneklerdeki gözlem sayılarını artırarak beklenen değerlerde artışa gidilmesidir (Büyüköztürk, 2014). Bu çalışmada da belirlenen değeri aşan gözenek sayılarındaki fazlalıktan dolayı likert maddelerinde birleştirmeye gidilmiştir. 'Hiçbir zaman', 'nadiren' ve 'bazen' maddeleri birleştirilerek 'ara sıra' ismiyle analize dâhil edilmiştir. Baştaki 'ara sıra' kategorisi 'çoğunlukla' olarak değiştirilmiş 'her zaman' kategorisi de aynı ismiyle korunmuştur.

\section{Bulgular}

Öğretmenlerin belirledikleri hedeflere ulaşmak için etkinlik planı hazırlama ve uygulama aşamalarında hangi değerlendirme sorusunu tercih ettikleri ile ilgili sonuçlar Tablo 2'de belirtilmiştir. Ayrıca tercih ettikleri değerlendirme sorularını kullanım sıklıklarının değerlendirme konusu üzerine seminer alma durumuna göre farklılık gösterip göstermediği ile ilgili kay-kare testi sonuçları da Tablo 3'te verilmiştir. Bu tablo, her bir değerlendirme soru türüne göre (betimleyici, duyuşsal, kazanımlara ve göstergelere yönelik, yaşamla ilişkilendirme soruları) ayrı ayrı yapılan kay- kare testinin ortak gösterimi şeklinde değerlendirilmelidir.

Tablo 2. Okul Öncesi Öğretmenlerinin Değerlendirme Sorularını Tercihlerinin Dağılımı

\begin{tabular}{|c|c|c|c|c|}
\hline $\begin{array}{r}\text { Tercih Edilen } \\
\text { Değerlendirme } \\
\text { Soruları }\end{array}$ & $\begin{array}{l}\text { Betimleyici } \\
\text { sorular }\end{array}$ & $\begin{array}{l}\text { Kazanım ve } \\
\text { göstergelere } \\
\text { yönelik sorular }\end{array}$ & $\begin{array}{l}\text { Duyuşsal } \\
\text { sorular }\end{array}$ & $\begin{array}{l}\text { Yaşamla } \\
\text { ilişkilendirme } \\
\text { soruları }\end{array}$ \\
\hline Hedefler & $\mathrm{F} / \%$ & $\mathrm{~F} / \%$ & $\mathrm{~F} / \%$ & $\mathrm{~F} / \%$ \\
\hline $\begin{array}{l}\text { 'farklı ögrenme merkezlerinde } \\
\text { cevaplanabilecek soruları hazırlama' }\end{array}$ & $\begin{array}{c}160 \\
(\% 49.5)\end{array}$ & $\begin{array}{c}126 \\
(\% 39.0)\end{array}$ & $\begin{array}{c}22 \\
(\% 6.8)\end{array}$ & $\begin{array}{c}15 \\
(\% 4.6)\end{array}$ \\
\hline $\begin{array}{l}\text { 'çocukların becerilerini üst düzeye } \\
\text { çıarabilecek nitelikte sorular hazırlama' }\end{array}$ & $\begin{array}{c}116 \\
(\% 35.9)\end{array}$ & $\begin{array}{c}158 \\
(\% 48.9)\end{array}$ & $\begin{array}{c}17 \\
(\% 5.3)\end{array}$ & $\begin{array}{c}32 \\
(\% 9.9)\end{array}$ \\
\hline $\begin{array}{l}\text { 'gelişim takibi amacıla gelişim özellikleri } \\
\text { dikkate alınarak sorular sorma' }\end{array}$ & $\begin{array}{c}93 \\
(\% 28.8)\end{array}$ & $\begin{array}{c}76 \\
(\% 23.5)\end{array}$ & $\begin{array}{c}84 \\
(\% 26.0)\end{array}$ & $\begin{array}{c}70 \\
(\% 21.7)\end{array}$ \\
\hline 'sorularla gün sonu değerlendirme yapma' & $\begin{array}{c}102 \\
(\% 31.6)\end{array}$ & $\begin{array}{c}128 \\
(\% 39.6)\end{array}$ & $\begin{array}{c}66 \\
(\% 20.4)\end{array}$ & $\begin{array}{c}27 \\
(\% 8.4)\end{array}$ \\
\hline
\end{tabular}


Tablo 2 incelendiğinde, öğretmenler etkinlik planlarını hazırlarken farklı öğrenme merkezlerinde cevaplanacak şekilde \%49.5'lik oranla betimleyici soruları tercih ettikleri belirlenmiştir. Çocukların farklı öğrenme merkezlerinde etkinliklerine devam ederken öğretmenlerin yalnızca \%4.6'lık kısmı değerlendirme yapmak için yaşamla ilişkilendirme sorularını hazırladıklarını ifade etmişlerdir. Öğretmenlerin eğitimin değerlendirme sürecinde belirledikleri bir diğer hedef çocukların becerilerini üst düzeye çıkarabilmek olup, bu amaç için öğretmenlerin \%48.9'unun kazanım ve göstergelere yönelik soruları, \%35.9'unun da betimleyici soruları hazırladığı sonucuna ulaşılmıştır. Duyuşsal sorular ise bu hedef için öğretmenlerin yalnızca \%5.3'ü tarafindan tercih edilmiştir.

Genel tabloya bakıldığında öğretmenlerin soru tercihleri arasında en dengeli dağılım, çocukların gelişim takiplerinin yapılması amacıyla sordukları sorularda olmuştur. Öğretmenler, gelişim takibini değerlendirmek için sırasıyla betimleyici soruları (\%28.9), duyuşsal soruları (\%26.0), kazanım ve göstergelere yönelik soruları (\%23.5) ve son olarak da yaşamla ilişkilendirme sorularını (\%21.4) tercih ettiklerini belirtmişlerdir. Tablo 2 incelendiğinde, öğretmenlerin yalnızca $\% 8,4$ 'ü gün sonu değerlendirme yapabilmek için yaşamla ilişkilendirme sorularını kullandıklarını belirtirken, bu amaç için \%39.6'lık bir oranla en çok kazanım ve göstergelere yönelik soruları tercih ettikleri bulunmuştur. Genel olarak Tablo 2 incelendiğinde öğretmenlerin hedeflerine ulaşmak için betimleyici ve kazanım ve göstergelere yönelik soruları tercih etme eğiliminde oldukları, yaşamla ilişkilendirme sorularını ise en az tercih edilen değerlendirme sorusu olarak ifade ettikleri belirlenmiştir.

Tablo 3'te, ögretmenlerin etkinlik planını hazırlarken ve uygularken kullandıkları değerlendirme sorularını kullanım sıklıklarının değerlendirme konusu üzerine seminer/eğitim alma durumlarına göre farklılık gösterip göstermediği ile ilgili kay-kare testi sonuçlarına yer verilmiştir.

Okul öncesi eğitimde değerlendirme konusu üzerine eğitim alan öğretmenlerin \% 36.7'si, 'farklı öğrenme merkezlerinde cevaplanabilecek soruları hazırlama' amacına yönelik olarak betimleyici soruları her zaman kullanılırken, eğitim almayan öğretmenlerin \%48.8'i yalnızca arasıra tercih ettiklerini belirtmiştir. Bu amaç doğrultusunda, duyuşsal sorular eğitim alan ve almayan öğretmenler tarafından sırasıly \% $\% 50.0$ ve \% 46.4 oranıyla çoğunlukla tercih edilmektedir. Eğitim alan öğretmenlerin \%20'si kazanımlara ve göstergelere yönelik soruları ara sıra tercih ederlerken, eğitim almayan öğretmenler bu değerlendirme sorusunu \%23.2'lik benzer bir oranla her zaman kullanmaktadır. Son olarak farklı eğitim ortamlarında cevaplanabilmesi için yaşamla ilişkilendirme soruları, eğitim alan öğretmenler tarafından \%40’lık bir oranla çoğunlukla tercih edilirken, eğitim almayan öğretmenlerin \%42'si bu sorulara yalnızca arasıra yer vermektedir. Yapılan kay-kare sonuçlarına göre etkinlik planı hazırlama aşmasında tercih edilen betimleyici ve kazanımlara yönelik hazırlanan değerlendirme sorularının kullanım sıkları ile öğretmenlerin seminer/eğitim alma durumları arasında anlamı fark bulunmazken; $\chi^{2}(\mathrm{sd}=2$, $\mathrm{n}=323)=5,04, \quad \chi^{2}(\mathrm{sd}=2, \quad \mathrm{n}=323)=3,98, \mathrm{p}>.05$; öğretmenlerin duyuşsal ve yaşamla ilişkilendirme sorularını kullanım sıkları ile seminer/ eğitim alma durumları arasında anlamlı fark bulunmuştur; $\chi^{2}(\mathrm{sd}=2, \mathrm{n}=323)=9,11$ ve $\chi^{2}(\mathrm{sd}=2, \mathrm{n}=323)=7,54, \mathrm{p}<, 05$.

Tablo 3'te, 'çocukların becerilerini üst düzeye çıkarabilmek' amacıyla betimleyici sorular eğitim alan öğretmenler tarafından \%46.7 oranında her zaman, eğitim almayan öğretmenler tarafından ise \%37.7 oranında çoğunlukla tercih edilmektedir. Belirlenen amaç doğrultusunda eğitim alan ve almayan öğretmenlerin çoğunlukla tercihi duyuşsal sorular olmaktadır. Ayrıca seminer/ eğitim alan öğretmenlerin \%63.3'ü yaşamla ilişkilendirme sorularını her zaman tercih ederken, eğitim almayan öğretmenler bu soruları \%19.8'lik bir oranla arasıra tercih etmektedir. Kay-kare analizi sonucuna göre, öğretmenlerin kullandıkları değerlendirme soruları çocukların becerilerini üst düzeye çıkabilecek nitelikte hazırlama sıklıkları ile seminer/eğitim almış olmaları arasında anlamlı bir fark olmadığ 1 bulunmuştur; $\chi^{2}(\mathrm{sd}=2, \mathrm{n}=323)=4,567 ; \chi^{2}(\mathrm{sd}=2, \mathrm{n}=323)=5,370, \chi^{2}(\mathrm{sd}=2, \mathrm{n}=323)=6,806$ ve $\chi^{2}(\mathrm{sd}=2, \mathrm{n}=323)=5,554, \mathrm{p}>, 05$.

Öğretmenlerin yaklaşık \%50'nin, 'gelişim takibi amacıyla gelişim özelliklerini dikkate alarak' betimleyici, duyuşsal, kazanım ve göstergelere yönelik ve yaşamla ilişkilendirme sorularını, değerlendirme konusunda eğitim/seminer alsın almasın her zaman kullandıkları sonucuna ulaşılmıştır. Söz konusu amaç için öğretmenlerin büyük çoğunluğu her zaman belirtilen değerlendirme sorularını kullanmalarına rağmen, değerlendirme sorularını kullanım sıklıkları ile öğretmenlerin seminer/ eğitim alma durumları arasında anlamlı bir fark bulunmamıştır; $\chi^{2}(\mathrm{sd}=2, \mathrm{n}=323)=2,71 ; \chi^{2}(\mathrm{sd}=2, \mathrm{n}=323)=2,17, \chi^{2}(\mathrm{sd}=2, \mathrm{n}=323)=, 50$ ve $\chi^{2}(\mathrm{sd}=2, \mathrm{n}=323)=2,09, \mathrm{p}>, 05$.

Son olarak Tablo3'te seminer/ eğitim alan öğretmenler betimleyici soruları 'gün sonu değerlendirme yapma' amacıyla kullanım sıklıklarını \%43.3 ile her zaman olarak ifade ederken, eğitim almayan öğretmenlerin \%48.1 'i bu soruları arasıra kullandıklarını belirtmiştir. Ayrıca yaşamla ilişkilendirme soruları, eğitim/seminer alan 
öğretmenler tarafından gün sonu değerlendirme yapmak amacıyla \%43.3'lük bir oranla her zaman tercih edilirken, eğitim/seminer almayan öğretmenlerin \%24.2'si yalnızca arasıra bu soruları kullandıklarını belirtmiştir. Sonuç olarak kay kare sonuçlarına göre öğretmenlerin gün sonu değerlendirmesi yapmak için duyuşsal ve yaşamla ilişkilendirme sorularını kullanım sıklıkları ile seminer/eğitim alma durumları arasında anlamlı bir fark olmadığı bulunmuştur, $\chi^{2}(\mathrm{sd}=2, \mathrm{n}=323)=2,78$ ve $\chi^{2}(\mathrm{sd}=2, \mathrm{n}=323)=3,05, \mathrm{p}>, 05$. 
Tablo 3. Öğretmenlerin Seminer Alma Durumlarına Göre Tercih Ettikleri Değerlendirme Sorularını Kullanım Sıklıklarının Kay-Kare Testi Sonuçları*1

\begin{tabular}{|c|c|c|c|c|c|c|c|c|c|c|c|c|c|c|c|c|c|c|c|c|c|c|}
\hline \multirow[b]{2}{*}{ 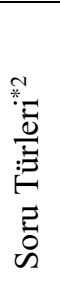 } & \multirow{2}{*}{\multicolumn{2}{|c|}{$\begin{array}{l}\text { Seminer } \\
\text { Alma } \\
\text { Durumu }\end{array}$}} & \multicolumn{5}{|c|}{$\begin{array}{l}\text { 'farklı ögrenme merkezlerinde } \\
\text { cevaplanabilecek soruları hazırlama' }\end{array}$} & \multicolumn{5}{|c|}{$\begin{array}{l}\text { 'becerileri üst düzeye çıkarabilecek } \\
\text { nitelikte sorular hazırlama' }\end{array}$} & \multicolumn{5}{|c|}{$\begin{array}{l}\text { 'gelişim takibi amaciyla gelişim } \\
\text { özellikleri dikkate alarak sorular sorma' }\end{array}$} & \multicolumn{5}{|c|}{ 'sorularla gün sonu değerlendirme yapma' } \\
\hline & & & 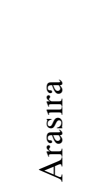 & 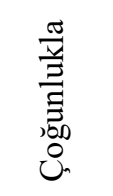 & 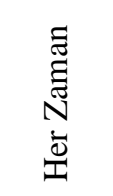 & $\mathrm{p}$ & $\chi^{2}$ & 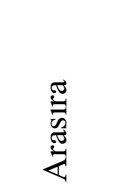 & 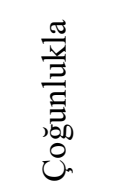 & 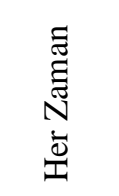 & $\mathrm{p}$ & $\chi^{2}$ & 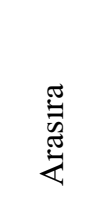 & 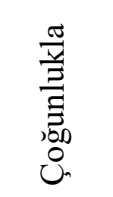 & 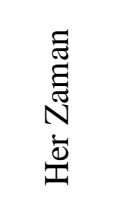 & $\mathrm{p}$ & $\chi^{2}$ & $\begin{array}{l}\frac{\pi}{3} \\
\frac{\pi}{4} \\
\frac{\pi}{4}\end{array}$ & 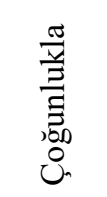 & 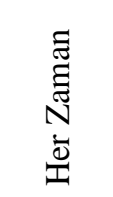 & $\mathrm{p}$ & $\chi^{2}$ \\
\hline \multirow{2}{*}{1} & Evet & $\begin{array}{l}\mathrm{N} \\
(\%)\end{array}$ & $\begin{array}{l}9 \\
(30.0)\end{array}$ & $\begin{array}{l}10 \\
(33.3)\end{array}$ & $\begin{array}{l}11 \\
(36.7)\end{array}$ & \multirow{2}{*}{.081} & \multirow{2}{*}{5.038} & $\begin{array}{l}8 \\
(26.7)\end{array}$ & $\begin{array}{l}8 \\
(26.7)\end{array}$ & $\begin{array}{l}14 \\
(46.7)\end{array}$ & \multirow{2}{*}{.102} & \multirow{2}{*}{4.567} & $\begin{array}{l}4 \\
(13.3)\end{array}$ & $\begin{array}{l}9 \\
(30.0)\end{array}$ & $\begin{array}{l}17 \\
(56.7)\end{array}$ & \multirow{2}{*}{.258} & \multirow{2}{*}{2.708} & $\begin{array}{l}11 \\
(36.7)\end{array}$ & $\begin{array}{l}6 \\
(20.0)\end{array}$ & $\begin{array}{l}13 \\
(43.3)\end{array}$ & \multirow{2}{*}{.041} & \multirow{2}{*}{6.412} \\
\hline & Hayır & $\begin{array}{l}\mathrm{N} \\
(\%)\end{array}$ & $\begin{array}{l}143 \\
(48.8)\end{array}$ & $\begin{array}{l}88 \\
(30.0)\end{array}$ & $\begin{array}{l}62 \\
(21.2)\end{array}$ & & & $\begin{array}{l}101 \\
(34.5)\end{array}$ & $\begin{array}{l}110 \\
(37.7)\end{array}$ & $\begin{array}{l}82 \\
(28.0)\end{array}$ & & & $\begin{array}{l}79 \\
(27.0)\end{array}$ & $\begin{array}{l}29 \\
(27.0)\end{array}$ & $\begin{array}{l}135 \\
(46.1)\end{array}$ & & & $\begin{array}{l}141 \\
(48.1)\end{array}$ & $\begin{array}{l}86 \\
(29.4)\end{array}$ & $\begin{array}{l}66 \\
(22.5)\end{array}$ & & \\
\hline \multirow[b]{2}{*}{2} & Evet & $\begin{array}{l}\mathrm{N} \\
(\%)\end{array}$ & $\begin{array}{l}3 \\
(10.0)\end{array}$ & $\begin{array}{l}15 \\
(50.0)\end{array}$ & $\begin{array}{l}12 \\
(40.0)\end{array}$ & \multirow[b]{2}{*}{.011} & \multirow[b]{2}{*}{9.106} & $\begin{array}{l}2 \\
(6.7)\end{array}$ & $\begin{array}{l}15 \\
(50.0)\end{array}$ & $\begin{array}{l}13 \\
(43.3)\end{array}$ & \multirow[b]{2}{*}{.068} & \multirow[b]{2}{*}{5.370} & $\begin{array}{l}7 \\
(23.3)\end{array}$ & $\begin{array}{l}5 \\
(16.7)\end{array}$ & $\begin{array}{l}18 \\
(60.0)\end{array}$ & & & $\begin{array}{l}9 \\
(30.0)\end{array}$ & $\begin{array}{l}10 \\
(33.3)\end{array}$ & $\begin{array}{l}11 \\
(36.7)\end{array}$ & \multirow[b]{2}{*}{.249} & \multirow[b]{2}{*}{2.779} \\
\hline & Hayır & $\begin{array}{l}\mathrm{N} \\
(\%)\end{array}$ & $\begin{array}{l}96 \\
(32.8)\end{array}$ & $\begin{array}{l}136 \\
(46.4)\end{array}$ & $\begin{array}{l}61 \\
(20.8)\end{array}$ & & & $\begin{array}{l}64 \\
(21.8)\end{array}$ & $\begin{array}{l}148 \\
(50.5)\end{array}$ & $\begin{array}{l}81 \\
(27.6)\end{array}$ & & & $\begin{array}{l}106 \\
(36.2)\end{array}$ & $\begin{array}{l}48 \\
(16.4)\end{array}$ & $\begin{array}{l}139 \\
(47.4)\end{array}$ & .338 & 2.168 & $\begin{array}{l}121 \\
(41.3)\end{array}$ & $\begin{array}{l}103 \\
(35.2)\end{array}$ & $\begin{array}{l}69 \\
(23.5)\end{array}$ & & \\
\hline \multirow[t]{2}{*}{3} & Evet & $\begin{array}{l}\mathrm{N} \\
(\%)\end{array}$ & $\begin{array}{l}6 \\
(20.0)\end{array}$ & $\begin{array}{l}12 \\
(40.0)\end{array}$ & $\begin{array}{l}12 \\
(40.0)\end{array}$ & \multirow[t]{2}{*}{.023} & \multirow[t]{2}{*}{7.536} & $\begin{array}{l}1 \\
(3.3)\end{array}$ & $\begin{array}{l}12 \\
(40.0)\end{array}$ & $\begin{array}{l}17 \\
(56.7)\end{array}$ & \multirow[t]{2}{*}{.033} & \multirow[t]{2}{*}{6.806} & $\begin{array}{l}5 \\
(16.7)\end{array}$ & $\begin{array}{l}9 \\
(30.0)\end{array}$ & $\begin{array}{l}16 \\
(53.3)\end{array}$ & .778 & .503 & $\begin{array}{l}9 \\
(30.0)\end{array}$ & $\begin{array}{l}8 \\
(26.7)\end{array}$ & $\begin{array}{l}13 \\
(43.3)\end{array}$ & \multirow[t]{2}{*}{.029} & \multirow[t]{2}{*}{7.112} \\
\hline & Hayır & $\begin{array}{l}\mathrm{N} \\
(\%)\end{array}$ & $\begin{array}{l}131 \\
(44.7) \\
\end{array}$ & $\begin{array}{l}94 \\
(32.1) \\
\end{array}$ & $\begin{array}{l}68 \\
(23.2) \\
\end{array}$ & & & $\begin{array}{l}68 \\
(23.2) \\
\end{array}$ & $\begin{array}{l}106 \\
(36.2) \\
\end{array}$ & $\begin{array}{l}119 \\
(40.6) \\
\end{array}$ & & & $\begin{array}{l}44 \\
(15.0) \\
\end{array}$ & $\begin{array}{l}107 \\
(36.5) \\
\end{array}$ & $\begin{array}{l}142 \\
(48.5) \\
\end{array}$ & & & $\begin{array}{l}160 \\
(54.6) \\
\end{array}$ & $\begin{array}{l}60 \\
(20.5) \\
\end{array}$ & $\begin{array}{l}73 \\
(24.9) \\
\end{array}$ & & \\
\hline \multirow[b]{2}{*}{4} & Evet & $\begin{array}{l}\mathrm{N} \\
(\%)\end{array}$ & $\begin{array}{l}7 \\
(23.3)\end{array}$ & $\begin{array}{l}12 \\
(40.0)\end{array}$ & $\begin{array}{l}11 \\
(36.7)\end{array}$ & \multirow[b]{2}{*}{.137} & \multirow[b]{2}{*}{3.982} & $\begin{array}{l}2 \\
(6.7)\end{array}$ & $\begin{array}{l}9 \\
(30.0)\end{array}$ & $\begin{array}{l}19 \\
(63.3)\end{array}$ & \multirow[b]{2}{*}{.062} & & $\begin{array}{l}5 \\
(16.7)\end{array}$ & $\begin{array}{l}6 \\
(20.0)\end{array}$ & $\begin{array}{l}19 \\
(63.3)\end{array}$ & & & $\begin{array}{l}5 \\
(16.7)\end{array}$ & $\begin{array}{l}12 \\
(40.0)\end{array}$ & $\begin{array}{l}13 \\
(43.3)\end{array}$ & & \\
\hline & Hayır & $\begin{array}{l}\mathrm{N} \\
(\%)\end{array}$ & $\begin{array}{l}123 \\
(42.0)\end{array}$ & $\begin{array}{l}85 \\
(29.0)\end{array}$ & $\begin{array}{l}85 \\
(29.0)\end{array}$ & & & $\begin{array}{l}58 \\
(19.8)\end{array}$ & $\begin{array}{l}110 \\
(37.5)\end{array}$ & $\begin{array}{l}125 \\
(42.7)\end{array}$ & & 5.554 & $\begin{array}{l}66 \\
(22.5)\end{array}$ & $\begin{array}{l}82 \\
(28.0)\end{array}$ & $\begin{array}{l}145 \\
(49.5)\end{array}$ & .352 & 2.089 & $\begin{array}{l}71 \\
(24.2)\end{array}$ & $\begin{array}{l}139 \\
(47.4)\end{array}$ & $\begin{array}{l}83 \\
(28.3)\end{array}$ & .218 & 3.046 \\
\hline
\end{tabular}

${ }^{*}$ Sonuçlar tablolaştırılırken, her soru türü için ayrı analiz yapılmış olup sonrasında tek tablo halinde gösterim yapılmıştır.

*2 1. Betimleyici sorular, 2. Duyuşsal sorular, 3. Kazanımlara ve göstergelere yönelik sorular, 4. Yaşamla ilişkilendirme soruları 


\section{Tartışma ve Sonuç}

$\mathrm{Bu}$ çalışmada okul öncesi öğretmenlerinin etkinlik planı hazırlarken ve uygularken hangi değerlendirme sorularını tercih ettikleri ve değerlendirme sorularını kullanım sıklıklarının değerlendirme konusu üzerine seminer/eğitim alma durumlarına göre farklılık gösterip göstermediği incelenmiştir. Analizler sırasında MEB Okul Öncesi Eğitim Programında program değerlendirmesinde ele alınan betimleyici, duyuşsal, kazanımlara ve göstergelere yönelik ve yaşamla ilişkilendirme soruları olarak tek tek ele alınmıştır.

Yapılan araştırma sonucunda, değerlendirme yapan okul öncesi öğretmenleri farklı öğrenme merkezlerinde öncelikle betimleyici soruları daha sonra kazanım ve göstergelere yönelik soruları ve de yaşamla ilişkilendirme sorularını tercih etmektedir. Bu sonuç alan yazında yapılan araştırmalarda çıkan öğretmenlerin değerlendirme süreçlerinde çoğunlukla alt düzey sorular ve kapalı uçlu soruları tercih ettikleri sonuçlarına paralellik göstermektedir (Bay,2016; Baysen, 2006; Lee, 2010; Storey, 2004). Bunun sebebi öğretmenlerin her öğrenme merkezinin dinamiğine göre değişmek zorunda kalacak olan açık uçlu sorular yerine hatırlama düzeyinde cevaplanacak soruları tercih etmeleri olabilir. Bu soruları hazırlamak ve cevaplarını almak daha kısa süre gerektirecektir ve yanıtlar daha gözlemlenebilir olacaktır. Öğretmenler ezbere dayalı ve bilgi tekrarına dayalı sorular hazırlaması daha pratik olması ve fazla bilgi gerektirmediği için tercih edilmiş olabilir. Büyükalan'ın (2002) belirttiği gibi bireyler daha çok bilgi edindikleri zaman üst düzey sorular sorabilirler, eğer öğretmenler kendi soru sorma becerilerini geliştirirlerse, farklı ortamlar ve farklı bireyler için soru çeşitliliğine sahip olabilirler. Ek olarak Vogler (2005) çalışmasında öğretmenlerin soru sormanın özelliklerini bilmeleri gerektiğinin ve bunları uygulamak ve daha çok soru sormak için istekli olmaları gerektiğinin altını çizmiştir. Bu çalışmanın sonucuna göre, öğretmenler her etkinlik türünde, eğitim süreci devam ederken ve günlük dilde de yeni soru kalıplarına yer verdikçe, farklı soru tiplerine aşina olacak kendi gelişimini sağlarken aynı zamanda çocuklara da model olabilecektir. Paralel olarak araştırmanın diğer bulgusunda çocuklar farklı öğrenme merkezlerinde çalışmalarına devam ederken, değerlendirme konusunda eğitim alan öğretmenlerin almayan öğretmenlere göre duyuşsal soruları kullanım sıklıkları arasında anlamlı bir fark görülmektedir. Eğitime katılan öğretmenlerin duyuşsal soruları kullanım sıklığı eğitim almayan öğretmenlerinkine göre daha yüksektir. Bu sonuç da göstermektedir ki öğretmenler eğitimlerle kendilerini desteklediklerinde, farklı öğrenme merkezleri için farklı değerlendirme soruları ile çocukların daha yaratıcı ve eleştirel şekilde düşünmelerine yardımcı olabilirler. Ayrıca, eğitimle birlikte öğretmenler, soruları daha somut, çocukların deneyimleri ile ilişkili, güncel olay ve nesneler üzerinden ve çocukların bildikleri kelimelerden oluşur şekilde hazırlayabilirler. Massey ve arkadaşlarının da (2008) belirttiği gibi öğretmenler tarafından eğitim sürecine daha çok soru dâhil edilmesi, çocukların katılımını destekleyecek ve farklı merkezler için farklı şekilde oluşturulan sorular, çocukların daha karmaşık ve detaylı düşünerek soruları yanitlamasıyla sonuçlanabilecektir.

Çalışmanın bir diğer sonucuna göre, çocukların becerilerini üst düzeye çıkarabilmek adına öğretmenlerin, benzer şekilde, duyuşsal ve yaşamla ilişkilendirme soruları yerine kazanımlara ve göstergelere yönelik soruları kullandıkları bulunmuştur. Burada şaşırtıcı olan belirlenen hedef çocukların becerilerini üst düzeye çekmek iken, öğretmenlerin üst düzey düşünmelerine firsat tanıyacak olan yaşamla ilişkilendirme sorularını yalnızca \%10luk bir oranla tercih etmeleridir. Bunun sebebi öğretmenlerin doğru sorular yöneltememe ve çocuklardan gelen sorulara uygun cevap verememe korkusu, çocukların yaratıcı düşünmeye yöneltecek olan açık uçlu sorular sormalarına engel olarak görülebilir. Bu bağlamda da öğretmenlerin lisans eğitiminde soru sorma becerilerini desteklemeye yönelik belirli bir dersin olmaması, konu ile ilgili uygulamaları derslerin eksikliği öğretmenlerin soru sorma becerilerinin tam anlamıla desteklenememesine neden olabilir. Ayrıca söz konusu becerinin desteklenmesi için de belirli kurs ya da eğitimlerin sunulması da öğretmenlerin tam anlamıyla bu beceriye sahip olmasında yeterli olmayabilir. Yapılan araştırmalarda da öğretmenlerin yüksek kalitede soru sorabilme becerileri kazanmaları için yeterli eğitimi aldıklarında, çocukların potansiyellerinin desteklendiği ve ilerleme kaydedildiği görülmektedir (Barnette, Orletsky, \& Sattes, 1994; Büyükalan Filiz, 2007; Storey, 2004; Zeegers \& Elliott, 2018). Ek olarak öğretmenlerin bilgi ve ezber düzeyinde kalan soruları, açık uçlu ve yaratıcılığı destekleyecek olan sorulara tercih etme sebepleri sınıf içinde daha fazla süreye ihtiyaç duymaları olabilir. Çünkü açık uçlu bir soru çocuklara yöneltildiğinde yeni sorular ortaya çıkabilecek, belirlenen hedefin dışında yeni odak noktaları oluşabileceği gibi öğretmende sınıf yönetimini kaybetme kaygısı ortaya çıkabilecektir (Chin \& Osborne, 2008). Bu sonuçla paralel olarak Waterhouse'un (1990) çalışmasında, soruları yanıtlamak için ayrılan süreden daha fazla zaman gerekiyor ve öğretmen yalnızca birkaç çocuğa soru yöneltiyorsa; bu durumda çocuklar etkinliğe dâhil olmayı bırakır ve sınıf yönetimi problemlerinin gözlenir sonucuna varılmıştır.

Çalışmanın bir diğer sonucuna göre öğretmenler çocukların gelişim özelliklerini göz önünde bulundurduklarında MEB programında belirtilen dört çeşit değerlendirme sorusunu dengeli bir dağılımla gelişim 
takibi amacıyla kullandıklarını ifade etmişlerdir. Ancak çalışmanın ikinci basamağında değerlendirme konusunda eğitim/seminer alan öğretmenle almayan öğretmenlerin değerlendirme sorularını kullanım sıklıkları arasında anlamlı fark bulunmamıştır. Bunun sebebi lisans eğitimi boyunca öğretmen adaylarına çocuğun gelişiminin bir bütün olarak ele alınması gerektiğinin aktarılması ve gelişim takibi için değerlendirmenin çok yönlü yapılması gerektiği bilgisi ile mezun olunması olabilir. Ayrıca öğretmenlerin dâhil oldukları eğitimlerin özellikle soru ve soru sorma temelli olmaması yalnızca eğitimde genel değerlendirme temelli olması da alınan eğitimin öğretmenlerin farklı değerlendirme sorularını kullanım sıklıkları üzerinde etkisi olmadığının sebebi olarak düşünülebilir.

Elde edilen bir diğer bulguda ise öğretmenlerin gün sonu değerlendirme için yine kazanım ve göstergelere yönelik soruları duyuşsal sorulara tercih ettikleri belirlenmiştir. Bunun sebebi ise öğretmenlerin kazanım ve göstergeler üzerinden oluşturdukları kontrol listesinin gün sonunda gözlemler aracılığıyla kısa sürede ve yüksek verimle tamamlanabilme ihtimali olabilir. Bu sonuç Carin, Bass ve Contant (2005)'ın çalışması ile paralellik göstermektedir. Söz konusu çalışmada da öğretilenlerin çocuklar üzerindeki yansımasının rahat bir şekilde belirlenebilmesi ve çocukların becerilerinin gözlemlenebilmesi için öğretmenlerin kapalı uçlu sorular tercih ettikleri belirlenmiştir. Böylelikle öğretmenlerin çocukların yanıtları üzerinden rahat bir değerlendirme yapabildikleri ifade edilmiştir. Ek olarak değerlendirme konusunda eğitim alan ve almayan öğretmenlerin değerlendirme sorularını kullanım sıklıkları arasındaki ilişkiye bakıldığında da betimleyici ve kazanımlara yönelik soruların kullanım sıklıkları arasında anlamlı bir ilişki söz konusudur. Bu sonuç öğretmenlerin eğitim aldıklarında süreç ve sonuç değerlendirmelerinde hangi soru türlerinin kullanmaları gerektiği bilgisine eriştikleri şeklinde yorumlanabilir. Çünkü yapılan çalışmada öğretmenler sonuç değerlendirmesi yaparken betimleyici ve kazanım ve göstergelere yönelik gibi daha çok hatırlama düzeyinde soruları tercih ettikleri, süreç değerlendirmesinde ise bu soruları arasıra veya çoğunlukla tercih ettikleri belirlenmiştir.

Sonuç olarak; birçok araştırma öğretmenin niteliğinin, çocukların özellikle de okul öncesi dönemdeki gelişimde çok büyük önemi olduğu vurgulanmaktadır (Burchinal, 2018; National Institute of Child Health and Human Development Early Child Care Research Network, 2002, 2005; Smolensky \& Gootman, 2003). Eğitimin önemli bir parçası kabul edilen değerlendirme süreci içinde de sorular ve cevapları; konu ile ilgili olarak varsayımları zorlayabilmek, çelişkileri ortaya koyabilmek ve yeni bilgiye ulaşabilmek için zengin bir araç olarak kullanılabilmektedir. Öğretmenlerin çocuklarına model olarak soru sorma ve sorgulama becerisinin keşfetmeye değer bir şey olduğunu yansıttıkları zaman, çocuklarda soru sormaktan keyif alarak yeni keşifler yapabilecektir. Çocukların sürece dâhil olarak daha fazla soru sormaları eğitimi daha etkili ve ilgi çekici kılarak (Kaya \& Elgun Ceviz, 2017) çocukların düşünme becerilerini desteklerken (King, 2005), çocukların soruları bir sonraki etkinliği şekillendirecek ve onların motivasyonları yükseltecektir (Chin \& Osborne,2008). Ayrıca kazanılan sorgulama becerisi ile çocukların konuları/olayları analiz etmelerine ve problemleri çözmelerine, yaşanılacak değişime uyum sağlamalarına ve dolayısıyla yeni firsatları belirleyerek yeni yönlere doğru gitmelerine yardımcı olacaktır. Bu bağlamda da problemden ziyade çözüme odaklanan bir öğretmenin ilk adımı soru sormak olmalıdır. Çünkü soru yoksa problem var demektir. Öğretmenler kendilerine her zaman şu soruyu sormalıdır; "Çocuklara ne/ler sorabilirim?” ve çocukların bu sorulara neler sorabileceği ile de sürekli düşünmeli ve hazır olabilmek için çalışmalarını sürdürmelidir. Bunun için de öğretmen çocuklarla ilgili olarak iyi bir dinleyici ve gözlemci olmayı sürdürmelidir. Eğitim sürecince öğretmenlerin sorularının, sınıftaki iletişimi kontrol dâhilinde yönlendirecek ve genişletecek en önemli araç (Yang, 2006) olarak görülmesi, eğitimde öğretmenlerin soru sorma becerilerini ne kadar önemsemeleri gerektiğinin de bir göstergesidir.

Alan yazın taraması yapıldığında değerlendirme soruları ile ilgili yapılan çalışmalar soruların yapıları (açıkkapalı uçlu) ya da bilişsel düzeylerine (hatırlama, anlama, uygulama, analiz etme, değerlendirme ve yaratma) odaklanarak gerçekleşirken bu çalışmada belirli olarak MEB okul öncesi programında yer verilen değerlendirme soruları üzerine yoğunlaşılmıştır. Odak noktası öğretmenlerin betimleyici, kazanım ve göstergelere yönelik, duyuşsal ve yaşamla ilişkilendirme sorularını kullanımlarına üzerine olmuştur. Bu çalışmanın, öğretmenlerin birebir uygulamada kullandıkları değerlendirme sorularına yönelik bir geribildirim sağlaması açısından alanyazına katkı sağlayacağı düşünülmektedir. Ancak söz konusu çalışma verileri online olarak düzenlenen anketle ve 323 öğretmen görüşü ile sınırlı tutulmuştur. Çalışmanın Türkiye genelinde daha çok öğretmenle yürütülmesi, öğretmenlerin değerlendirme sorularını kullanım tercihlerinin genellenebilirliğini artırabilir. Ayrıca, kullanılan anketin likert tipi sorulardan oluşması sebebiyle öğretmenlerin görüşleri nicel verilerle sınırlandırılmıştır. İlerleyen çalışmalarda söz konusu değerlendirme sorularının kullanıma ilişkin nitel bir çalışma ile öğretmenlerin 
değerlendirme sorularını kullanım tercihlerinin nedenleri, tercihlerinin olası sonuçları irdelenebilir. Ayrıca bir diğer çalışma, öğretmenlerin görüşleri ve eğitim ile ilgili politika belirleyicilerinin değerlendirme sorularına ilişkin görüşlerinin karşılaştırılması amacıyla yürütülebilir. Bu çalışmanın sonucunda, planlanan politikaların ne kadarının, nasıl uygulamaya konulup/konulamadığı ile ilgili yorumlar elde edilebilir. Böyle bir verinin Türkiye'de uygulanmakta olan eğitim programının değerlendirme basamağı için zengin bir geribildirim sağlayabileceği düşünülmektedir. Ek olarak, gerek okul öncesi öğretmen adaylarının gerekse öğretmenlerin katılabileceği özellikle okul öncesi dönem değerlendirmesini ve etkili soru sormayı içeren çalıştayların düzenlenmesi, öğretmenlerin soru sorma ile ilgili öz değerlendirmelerini yapmalarına firsat sunacaktır. Ayrıca hem araştırmacılar hem de alan uygulayıcılarına yönelik olarak, örnek durumlar üzerinden planlamalarla hazırlanabilecek online bir eğitim ya da uygulamanın hazırlanması önerilebilir. Böyle bir uygulama ile öğretmenler farklı örnek durumlarda kullanılabilecekleri nasıl farklı soru tiplerini hazırlayabileceklerini deneyimleyecek ve soru sorma pratiği kazanabileceklerdir. 


\section{References}

Anderson, L. W. (1999). Rethinking Bloom's Taxonomy: Implications for testing and assessment. ED 435630.

Barnette, J., Orletsky, S., \& Sattes, B. (1994). Evaluation of teacher classroom questioning behaviors. Office of Educational Research and Improvement. Washington, ERIC Education resources Information Center (ED 377188).

Bay, D. N. (2016). The question asking skills of preschool teacher candidate: Turkey and America example. Journal of Education and Training Studies, 4(1), 161-169.

Bay, D. N., \& Hartman, D. K. (2015). Teachers asking questions in preschool. International Journal of Humanities and Social Science, 5(7/1), 60-76.

Baysen, F. (2006). Öğretmenlerin sınıfta sordukları sorular ile öğrencilerin bu sorulara verdikleri cevapların düzeyleri [The levels of teacher questions and student answers]. Kastamonu Education Journal, 14(1), 21-28.

Borich, G. D. (2013). Effective teaching methods: Research- based practice (8th ed.). River, NJ: Pearson Education.

Bricker, D., Pretti-Frontczak, K., Johnson, J., \& Straka, E. (2002). Assessment, evaluation, and programming system for infants and children: Vol. 1. Administration guide (2nd ed.). Baltimore, MD: Paul H. Brooks.

Buldu, M. (2010). Do they walk the talk: An examination of Turkish in-service early childhood teachers' assessment practices. Master Thesis, Middle East Technical University, Ankara, Turkey.

Burchinal, M. (2018). Measuring early care and education quality. Child Development Perspectives, 12(1), 3-9.

Büyükalan, F. (2002). Soru cevap yöntemine ilişkin ögretimin ögretmenlerin soru sorma düzeyi ve tekniklerine etkisi [The effect of teaching of the question and answer method on teachers' questioning level and techniques]. Doctoral Dissertation, Gazi University, Ankara, Turkey.

Büyükalan Filiz, S. (2007). Öğretmenler için soru sorma sanatı [The art of questioning for teachers]. Ankara: Nobel Publishing.

Büyüköztürk, Ş. (2014). Sosyal Bilimler İçin Veri Analizi El Kitabı: İstatistik, Araştırma Deseni, SPSS Uygulamalart ve Yorum (Genişletilmiş 19. bs.) [Handbook of Data Analysis for Social Sciences: Statistics, Research Design, SPSS Applications and Interpretation (19th ed.)]. Ankara: Pegem Academy Publishing.

Büyüköztürk, Ş., Kılıç Çakmak, E., Akgün, Ö. E., Karadeniz, Ş., \& Demirel, F. (2014). Bilimsel Araştırma Yöntemleri (17. Bs.) [Scientific research methods (17th ed.)]. Ankara: Pegem Academy Publishing.

Carin, A., Bass, J., \& Contant, T. (2005). Methods for teaching science as inquiry. USA: Pearson Merrill Prentice Hall.

Cecil, L. N., \& Preifer, J. (2011). The art of inquiry questioning strategies for K-6 classrooms. Winnipeg, Canada: Portage \& Main.

Chin, C., \& Osborne, J. (2008). Students' questions: a potential resource for teaching and learning science. Studies in Science Education, 44(1), 1-39.

Dennis, L.R., Rueter, J.A. \& Simpson, C.G. (2014). Authentic assessment: Establishing a clear foundation for instructional practices. Florida State University Libraries. 1-22.

Downs, A., \& Strand, P. S. (2006). Using assessment to improve the effectiveness of early childhood education. Journal of Child and Family Studies, 15(6), 671-680. Doi: 10.1007/s10826-006-9080-7.

Erdoğan, I., \& Campbell, T. (2008). Teacher questioning and interaction patterns in classrooms facilitated with differing levels of constructivist teaching practices. International Journal of Science Education, 30(14), 18911914. 
Fisher, R. (1995). Teaching children to think. Cheltenham: Starney Thornes.

Fraenkel, J. R., \& Wallen, N. E. (2006). How to design and evaluate research in education (6th ed.). New York, NY: McGraw-Hill.

Can Gül, Ş. (2009). Okul öncesi ĕgitimi ögretmen ve öğretmen adaylarının 2006 okul öncesi ĕgitim programının değerlendirme unsuruna yönelik görüş ve davranışlarının incelenmesi [Investigaton of early childhood teachers' and student teachers' perceptions and behaviors about evaluation aspects of 2006 early childhood education program]. Master Thesis, Pamukkale University, Denizli, Turkey.

Günel, M., Kıngır, S. \& Geban, Ö. (2012). Argümantasyon Tabanlı Bilim Öğrenme (ATBÖ) yaklaşımının kullanıldığı sınıflarda argümantasyon ve soru yapılarının incelenmesi [Analysis of argumentation and questioning patterns in argument based inquiry classrooms]. Eğitim ve Bilim, 37(164), 316- 330.

Hanes, B. M. (2009). Perceptions of early childhood assessment among early childhood educators. Doctoral Dissertation, Widener University, Pennsylvania.

Kaya, İ. (2018). Examination of preschool teachers' opinion on alternative assessment. Universal Journal of Educational Research, 6(10), 2294-2299.

Kaya, S., \& Elgun Ceviz, A. (2017). Pre-service teachers' use of dynamic discourse variable during classroom teaching. Journal of Education and Practice, 8(12), 82-89.

King, D. (2005). Inquiry dialogue in the kindergarten: A teacher action research study. Doctoral Dissertation, Capella University, USA.

Kohn, A. (2015). Who's asking? Educational Leadership, 73(1), 16-22.

Krathwohl, D. R. (2002). A Revision of Bloom's Taxonomy: An Overview. Theory Into Practice, 41(4), $212-218$.

Lee, Y. (2010). Blended teacher supports for promoting open-ended questioning in pre-k science activities. Doctoral Dissertation, University of Virginia, USA.

MacNaughton, G., \& Williams, G. (2004). Teaching young children choices in theory and practice. Australia: Ligare.

Massey, S. L., Pence, K. L., Justice, L. M., \& Bowles, R. P. (2008). Educators' use of cognitively challenging questions in economically disadvantaged preschool classroom contexts. Early Education and Development, 19(2), 340-360. Doi: 10.1080/10409280801964119.

McComas, W. F., \& Abraham Rossier, L. (2005). Asking more effective questions. Retrieved from https://uwaterloo.ca/centre-for-teaching-excellence/sites/ca.centre-for-teachingexcellence/files/uploads/files/asking_better_questions.pdf

Meacman, S., Vukelich, C., Han, M., \& Buell, M. (2014). Preschool teachers' questioning in sociodramatic play. Early Childhood Research Quarterly, 29(4), 562-573.

Mercer, N. \& Howe, C. (2012). Explaining the dialogic processes of teaching and learning:The value of sociocultural theory. Learning, Culture and Social Interaction, 1(1), 12-21.

Milli Eğitim Bakanlığı (MEB) [Ministry of National Education (MoNE)] (2013). MEB Okul Öncesi Ĕ̆itim Programı 2013 [Ministry of National Education Early Childhood Education Program 2013]. Ankara, Turkey: Milli Eğitim Bakanlığg.

Muijs, D., \& Reynolds, D. (2005). Effective Teaching - Evidence and Practice. London: Sage.

MyHill, D., \& Dunkin, F. (2002). What is a good question? LITERACY Today, 33, 8-10.

Nassaji, H., \& Wells, G. (2000). What's the use of Triadic Dialogue? An investigation of teacher-student interaction. Applied Linguistics, 21(3), 376-406. 
National Institute of Child Health and Human Development Early Child Care Research Network. (2002). Early child care and children's development prior to school entry: Results from NICHD Study of Early Child Care. American Educational Research Journal, 39(1), 133-164.

National Institute of Child Health and Human Development Early Child Care Research Network (Eds.). (2005). Child care and child development: Results from the NICHD Study of Early Child Care and Youth Development. New York, NY: Guilford Press.

Nystrand, M., Wu, L. L., Gamoran, A., Zeiser, S. \& Long, D. A. (2003). Questions in time: Investigating the structure and dynamics of unfolding classroom discourse. Discourse Processes, 35(2), 135-198.

Petty, G. (1993). Teaching today (a practical guide). Cheltenham: Stanley Thornes.

Scott, P. H., Mortimer, E. F. \& Aguiar, O. G. (2006). The tension between authoritative and dialogic discourse: A fundamental characteristic of meaning making interactions in high school science lessons. Science Education, 90(4), 605-631.

Sellappah, S., Hussey, T., Blackmore, A. M., \& McMurray, A. (1998). The use of questioning strategies by clinical teachers. Journal of Advanced Nursing, 28(1), 142-148.

Smolensky, E., \& Gootman, J. A. (Eds.). (2003). Working families and growing kids: Caring for children and adolescents. Washington, DC: National Academies.

Storey, S. (2004). Teacher questioning to improve early childhood reasoning. Doctoral Dissertation, Arizona University, USA.

Tan, Z. (2007). Questions in Chinese University EL classrooms: what lies beyond it? RELC, 38(1), 87-103.

Turupcu, A. (2014). Observation as an assessment tool in early childhood education: A phenomenological case study of teacher views and practices. Master Thesis, Middle East Technical University, Ankara, Turkey.

Vogler, K. E. (2005). Improve Your Verbal Questioning. The Clearing House, 79(2), 98-103.

Waterhouse, P. (1990). Classroom Management (The Teaching and Learning Series). Stafford: Network Educational Press.

Yang, M. (2006). A critical review of research on questioning in education: limitations of its positivistic basis. Asia Pacific Education Review, 7(2), 195-204.

Yip, D. Y. (2004). Questioning skills for conceptual change in science instruction. Journal of Biological Education, 38(2), 76-83.

Yurdabakan, İ. (2012). Bloom'un revize edilen taksonomisinin eğitimde ölçme ve değerlendirmeye etkileri [The effects of Bloom's revised taxonomy on measurement and evaluation in education]. Gaziantep University Journal of Social Science, 11(2), 327- 348.

Zeegers, Y. \& Elliott, K. (2018) Who's asking the questions in classrooms? Exploring teacher practice and student engagement in generating engaging and intellectually challenging questions, Pedagogies: An International Journal, DOI: 10.1080/1554480X.2018.1537186 